\title{
Archean S-Type granites: petrology, geochemistry and geochronology of the Lekkersmaak and Willie plutons, Kaapvaal Craton, South Africa
}

Marc Poujol $^{1}$, Justine Jaguin ${ }^{1}$, Jean-François Moyen ${ }^{2}$, Philippe Boulvais ${ }^{1}$, Jean-Louis Paquette ${ }^{3}$

1 Univ. Rennes, CNRS, Géosciences Rennes - UMR 6118, F-35000 Rennes, France ; marc.poujol@univ-rennes1.fr, justine.jaguin@gmail.com,philippe.boulvais@univ-rennes1.fr

2 Université de Lyon, Laboratoire Magmas et Volcans, UJM-UCA-CNRS-IRD, 23 rue Dr. Paul Michelon, F-42023 Saint Etienne, France. On sabbatical at School of Earth, Environment and Atmosphere Sciences, Monash University, Clayton, VIC 3168, Australia; jean.francois.moyen@univ-st-etienne.fr

3 Université Clermont Auvergne, CNRS-IRD-OPGC, Laboratoire Magmas et Volcans, F-63000 Clermont-Ferrand, France ; J.L.Paquette@opgc.univ-bpclermont.fr

\begin{abstract}
S-type granites correspond to reworking of pre-existing continental material and form by partial melting of (meta)sediments. Early-to-mid Archean S-type granites are rare and are more frequently found, usually as relatively small intrusions, during the Neoarchean and the Archean-Proterozoic transition. In the context of Archean geology, their paucity is therefore significant, in that it matches the uncommon nature of processes during this period. In this study, we focus on the Late Mesoarchean Willie pluton and Neoarchean Lekkersmaak pluton, which crop out to the south of the Murchison Greenstone Belt in the Northern Kaapvaal Craton, South Africa. These intrusions represent the oldest S-type plutons known so far in the region. We constrain their petrogenesis by documenting their petrology, mineralogy (mineral composition), geochemistry (major and trace elements, $\mathrm{Sr}, \mathrm{Nd}$ and $\mathrm{O}$ isotopes) and zircon U-Pb geochronology. The large Lekkersmaak and smaller Willie plutons represent two granites sharing many geochemical characteristics; they are both peraluminous, Ms-bearing S-type granites although they are more sodic and less potassic than typical S-type granites. The Willie granite was emplaced $2816 \pm 9$ Ma ago while the Lekkersmaak yielded an emplacement age of $2771 \pm 2 \mathrm{Ma}$. Therefore, S-Type magmatism in the area occurred twice at $2.82 \mathrm{Ga}$ and then $40 \mathrm{Myr}$ later at $2.77 \mathrm{Ga}$, involving comparable immature metasedimentary sources and conditions of partial melting. Finally, a sample from the Lekkersmaak pluton devoided of S-type features as it is muscovite-free and aluminum poor was emplaced $2734 \pm 11$ Ma ago. This confirms that the magmatic activity south of the Murchison Greenstone Belt was episodic as stated in previous studies.
\end{abstract}




\section{Introduction}

S-type granites are interpreted as forming by melting of (meta)sediments. Therefore, they correspond to reworking of pre-existing continental material, often having witnessed several cycles of weathering, erosion and deposition (Chappell, 1984; Clemens, 2003; White et al., 1986). Early-to-mid Archean S-type granites are rare (Moyen, 2019) although they became more common during the Neoarchean and the Archean-Proterozoic transition, yet often as small size intrusions (see Bucholz and Spencer, 2019 and references therein). In the context of Archean geology, their paucity (Moyen, 2019) is therefore significant, in that it matches the uncommon nature of processes associated with maturing continental crust and crustal thickening, including erosion and deposition of clastic sediments, and burial, metamorphism and melting of these sediments. The relatively rare examples that are described (Laurent et al., 2014; Moyen, 2019) occur late in the evolution of cratons, and mark the transition from the early phase of greenstone-granites (TTG) accretion, to later stabilization events. They are critical markers of craton stabilization and transition towards processes more akin to those occurring on the modern Earth (Cawood et al., 2018).

The chemistry of S-type granites is characterized by high-alkali and aluminum contents (e.g. Clemens and Vielzeuf, 1987; Clemens, 2003). This can be expressed in terms of $\mathrm{A} / \mathrm{CNK}\left(\mathrm{Mol} \mathrm{Al}_{2} \mathrm{O}_{3} /\left(\mathrm{Na}_{2} \mathrm{O}+\mathrm{K}_{2} \mathrm{O}+\mathrm{CaO}\right)\right.$ ratio), that is greater than 1.1, normative corundum position in A'CF diagram (eg. (White and Chappell, 1983) or similar properties. Mineralogically, the peraluminous nature is reflected by the presence of minerals such as cordierite, garnet or muscovite. Although some of these features are common to all fractionated granites (Chappell, 1999), collectively converging to the slightly peraluminous composition of the granitic minimum (Bonin et al., 2020; Chappell, 1999; Villaseca et al., 1998), an important trait of S-type granites is that they remain peraluminous at all differentiation levels, and of course the rest of their properties (i.e. trace elements, isotopic compositions, zircon inheritance...) are in agreement with a sedimentary source. They are, as such, a relatively easy rock type to identify.

In this study, we focus on the Neoarchean $430 \mathrm{~km}^{2}$ Lekkersmaak and the small ca. 2.82 Ga Willie plutons (Poujol, 2001; Anhaeusser, 2006; Zeh et al., 2009), which crop out to the south of the Murchison Greenstone Belt in the Northern Kaapvaal Craton (Fig. 1a). These intrusions represent the oldest large S-type plutons known so far in the region. We constrain the petrogenesis of the Lekkersmaak and Willie plutons by 
documenting their petrology, mineralogy (mineral composition), geochemistry (major and trace elements, $\mathrm{Sr}$, $\mathrm{Nd}$ and $\mathrm{O}$ isotopes) and zircon $\mathrm{U}-\mathrm{Pb}$ geochronology.

\section{Geological setting: The Murchison greenstone and granitoids terrain}

The Murchison granitoid Greenstone Terrane is located in the northeast of the Kaapvaal Craton (Fig. 1a), 70 $\mathrm{km}$ to the south of the Limpopo Belt (Hout River Shear Zone) and the Giyani and Pietersburg Greenstone Belts. De Wit et al. (1992) argued that various crustal blocks made up the Kaapvaal Craton, one of the sutures being the Thabazimbi-Murchison Lineament (TML) that is described as separating the Witwatersrand Block to the south from the Pietersburg Block to the north. This TML (Du Plessis, 1991) is a craton-scale geophysical feature (Vinnik et al., 1995), but its exact location in the vicinity of the Murchison belt remains unclear (Fripp et al., 1980; de Wit et al., 1992; Anhaeusser, 2006; Zeh et al., 2013). Regardless of its exact location within the belt, the study by Zeh et al. (2013) confirmed that the TML represents an important Archean suture zone, formed by the $2.97 \mathrm{Ga}$ collision between a back-arc system to the north and an evolved terrane to the south.

The Murchison Greenstone Belt is a narrow (10-15 km) east-northeast trending 3.09 to $2.97 \mathrm{Ga}$ old volcano-sedimentary sequence (Poujol et al., 1996) with a depth for the greenstone-basement interface comprised between 4 and 9-12 km in the centre (de Beer et al., 1984). The surrounding granitoids, which were emplaced over a period of $300 \mathrm{Myr}$ (Poujol et al., 2003), present variable geochemical compositions ranging from granodiorite to leucogranite (see below). Dating of synkinematic intrusions, fluid circulations and metamorphic overprints between $2.97 \mathrm{Ga}$ and ca. $2.80 \mathrm{Ga}$ have indicated that the tectonic history of the terrane was protracted (e.g. Vearncombe, 1988; Poujol et al., 1996; Poujol and Robb, 1999; Poujol, 2001; Zeh et al., 2009; Jaguin et al., 2012a; Block et al., 2013).

The geological history of the Murchison Belt started prior to 3.09 Ga with deposition of the mafic and ultramafic komatiitic Mulati and Leydsorp Formations (Poujol, 2001) followed, at 3.09 Ga, by the emplacement of the mafic-to-felsic volcanic rocks of the Weigel Formation (Poujol et al., 1996). This episode was coeval with the intrusion of the Harmony granite and tonalitic phases farther to the south (Fig. 1a; Poujol and Robb, 1999).

Around 2.99-2.97 Ga, felsic volcanites of the Rubbervale Formation emplaced to the north (Poujol et al., 1996; Brandl et al., 1996; Poujol, 2001) while some sedimentary rocks deposited in the center, among which the La France Formation (Zeh et al., 2013; Fig 1b). The La France Formation is a small area in the 
south-center part of the belt that comprises quartzites as well as kyanite and staurolite-bearing micaschists, indicating recrystallization under amphibolite facies conditions (Block et al., 2013). Important plutonic activity is largely documented between 2.97 and $2.92 \mathrm{Ga}$ (Baderoukwe granodioritic batholith, Jaguin et al., 2012b; Discovery granite, Poujol, 2001; Rooiwater gabbro-diorite complex, Zeh et al., 2013), and may be related to the accretion between the northern and the southern terranes (Zeh et al., 2013).

After a magmatic quiescent period, a third period of activity occurred between 2.84 and $2.77 \mathrm{Ga}$. It comprises the peraluminous Willie and Lekkersmaak plutons (Vearncombe et al., 1992) which crystallized at $2820 \pm 38$ Ma and $2795 \pm 8$ Ma (Poujol, 2001; Zeh et al., 2009, respectively), the Duiwelskloof "granite" ("granite" is used with caution without proper petrographic nor geochemical information) and related gneissic phase (2841 $\pm 10 \mathrm{Ma}$ and $2776 \pm 10 \mathrm{Ma}$, Laurent et al., 2013; $2839 \pm 8$ Ma and $2784 \pm 8$, Zeh et al., 2009), the granite-granodiorite Turfloop batholith $(2777 \pm 10 \mathrm{Ma}$, Henderson et al., 2000), and pegmatitic dykes intrusive into the Makhutswi gneiss (2848 \pm 58 Ma, Poujol and Robb, 1999). This activity is contemporaneous with fluid circulation, albitization and deformation in the Antimony Line, a structure within the Murchison Belt hosting antimony and gold deposits (Jaguin et al., 2013; 2014). Finally, to the south of the belt, the Mashishimale pluton, a polyphased bt \pm hbl monzogranite (Villaros et al., 2011), as an age of at ca $2.67 \mathrm{Ga}$ (Poujol, 2001; Zeh et al., 2009).

The Lekkersmaak pluton corresponds to a bi-lobate, $40 \mathrm{~km}$ long, maximum $20 \mathrm{~km}$ wide, ENEelongated body (Fig. 1b, Geological Survey of South Africa, map of Tzaneen, 1985; Vearncombe et al., 1992). It includes porphyritic facies in its central part and in its western termination, the so-called "Willie Granite". Basement remnants are present in the core of the intrusive body (white zones in Fig. 1b), probably indicating that the body is thin and presents a laccolith-like shape. This seems to be confirmed by the geophysical study of de Beer (1982). Finally, the Lekkersmaak pluton includes, in places, large enclaves or rafts of mafic lithologies (grey zones in Fig. 1b). Several geochronological studies were performed on this pluton. Burger and Walraven (1979) reported a U-Pb zircon age of $2690 \pm 25$ Ma. Barton (1984) published a whole rock RbSr isochron age of $2581 \pm 252 \mathrm{Ma}\left(\mathrm{I}_{\mathrm{Sr}}=0.702 \pm 0.004\right)$ and three $\mathrm{Rb}-\mathrm{Sr}$ ages obtained on biotite at $1348 \pm 27$ Ma, $1383 \pm 28$ Ma and $1297 \pm 26$ Ma respectively. More recently Zeh et al. (2009) reported in-situ U-Pb zircon age of $2795 \pm 8 \mathrm{Ma}$. 


\section{Sampling and samples}

The poor outcrop conditions together with the development of heavily fenced game farms prevented an optimal observation and sampling. Nevertheless, we managed to collect samples from east to west and from edge to core for the Lekkersmaak pluton (Fig. 1b), together with one sample from the Willie granite. These samples are therefore representative of the textural and petrographic variety of the pluton. Their locations are provided in Supplementary Table 1.

Samples are light-grey to yellow leucocratic rocks (Fig. 2a, b and c). Their mineralogy consists of quartz with undulose extinction, plagioclase (commonly zoned, sometimes poikilitic, and sometimes pervasively sericitized), orthose and microcline, dark biotite and muscovite (Fig. 2d). Garnet was found in only one sample (MUR 09-67). Epidote and titanite are common accessory minerals, often associated with biotite (Fig. 2e) and other accessory minerals such as sulfides, apatite and zircon. Texturally, most of the pluton presents a medium- (MUR 09-67, Fig. 2a) to coarse-grained (MUR 09-108) equigranular facies, but, in some places, porphyritic facies occur (cm-long orthose, MUR 09-66A, Fig. 2b). Samples MUR 09-60, 61 and 80 have a slightly gneissic aspect evidenced by a diffuse quartz appearance and an anisotropic orientation of the biotite grains. MUR 09-72 is a foliated rock (Fig. 2c) collected along the northern margin of the intrusion. Tourmaline-pegmatite rocks have been observed in some place along this margin (close to MUR 09-60 sample site) or in the core of the pluton (close to MUR 09-64 sample site). MUR 09-63 is made of poecilitic plagioclase and quartz, very rare muscovite but abundant chlorite associated with opaque minerals. This sample shows veinlets of quartz-plagioclase with some myrmekitic textures. Sample MUR 09-64 is a coarse-grained leucocratic rock, without muscovite or biotite but made of poecilitic plagioclase and quartz, the latter forming diffuse pseudo-veins, as well as some apatite and epidote as accessory phases.

\section{Analytical procedures}

\section{Mineral and whole rock elementary composition}

Mineral compositions were measured in thin section using a SX-100 CAMECA electron microprobe (EMP) at the Laboratoire Magmas et Volcans (Clermont-Ferrand, France) using a 15kV accelerating voltage. Results are presented in Table 1. 
For whole rock composition, rocks were crushed first in a steel crusher then in an agate mortar until a fine powder was obtained. The SARM laboratory (CRPG-CNRS, Nancy, France) performed the chemical analyses using $\mathrm{LiBO}_{2}$ fusion and acid dissolution by ICP-AES for major elements and ICP-MS for trace elements (details in Carignan et al., 2001). Whole rock chemical compositions are reported in Table 2, together with the detection limits. Analytical uncertainties depend on the content and can be found on the SARM webpage (http://helium.crpg.cnrs-nancy.fr/SARM/pages/roches.html) or in Carignan et al. (2001).

\section{Nd and Sr isotope systematics}

$\mathrm{Sr}$ and $\mathrm{Sm}-\mathrm{Nd}$ isotope analyses were performed on $100 \mathrm{mg}$ of rock powders using the 7-collector Finnigan MAT-262 mass spectrometer available at the GeOHeLiS analytical platform (Univ. Rennes 1, France). Powders were dissolved twice with a mixture of concentrate $\mathrm{HF}-\mathrm{HNO}_{3}$ acids. After five days of digestion, the solution was evaporated to dryness and then taken up in $6 \mathrm{~N} \mathrm{HCl}$ acid for two days. They were then dried and taken up with concentrated $\mathrm{HCl} 2.5 \mathrm{~N}$ and loaded on cation exchange chromatography columns using AG50W-X8 resin to collect the REE fractions on one hand and Sr on the other. The REE fractions were then purified and Sm and Nd isolated using a secondary column loaded with Eichrom Ln resin. Sr was separated with the Sr Spec resin. Sm-Nd concentrations were measured by isotope dilution using a ${ }^{149} \mathrm{Sm} /{ }^{150} \mathrm{Nd}$ spike. Samples were spiked before dissolution. During the analytical session, measurements of the AMES Nd standard gave a mean ${ }^{143} \mathrm{Nd} /{ }^{144} \mathrm{Nd}$ ratio of $0.511957 \pm 3(\mathrm{n}=18)$, and analyses of the NBS-987 $\mathrm{Sr}$ standard yielded a mean ${ }^{87} \mathrm{Sr} /{ }^{86} \mathrm{Sr}$ ratio of $0.710183 \pm 10(\mathrm{n}=18)$. Blanks values for $\mathrm{Nd}$ and $\mathrm{Sr}$ were $<300 \mathrm{pg}$ and therefore considered as negligible. ${ }^{87} \mathrm{Rb} /{ }^{86} \mathrm{Sr}$ was calculated using $\mathrm{Rb}$ and $\mathrm{Sr}$ contents from ICP-MS measurements and a ${ }^{87} \mathrm{Rb}$ abundance of $27.8346 \%$. $\mathrm{I}_{\mathrm{Sr}}\left(\mathrm{i} . \mathrm{e}^{87} \mathrm{Sr} /{ }^{86} \mathrm{Sr}\right.$ initial ratio) was calculated using the decay constant $\lambda=1.42 \times 10^{-11} \mathrm{y}^{-1}$. Model ages and $\varepsilon_{\mathrm{Nd}}$ were calculated using the decay constant $\lambda=6.54 \times 10^{-12} \mathrm{y}^{-1}$ and the parameters of Goldstein et al. (1984).

\section{Oxygen isotope systematics}

Oxygen isotope whole rock analyses (Table 2) were carried out in Geosciences Rennes (France). About $7 \mathrm{mg}$ of whole rock powder were reacted with $\mathrm{BrF}_{5}$ in $\mathrm{Ni}$ tubes at $670^{\circ} \mathrm{C}$ overnight (after the method of Clayton and Mayeda, 1963). It was then converted to $\mathrm{CO}_{2}$ by reaction with hot graphite, and analyzed using a VG SIRA 10 triple collector instrument. Long-term analysis of NBS 28 standard $\left(\delta^{18} \mathrm{O}=9.58 \%\right)$ gave a mean value of 
$9.3 \pm 0.1 \%$. Measured values have thus been slightly corrected. The average uncertainty on oxygen isotope composition is $0.2 \%$.

\section{$\mathrm{U} / \mathrm{Pb}$ zircon dating}

Zircon grains were dated by in-situ LA-ICP-MS analyses on separated grains mounted in epoxy mounts. A classic mineral separation procedure has been applied. From the powder fraction $(<250 \mu \mathrm{m})$ of the crushed rocks, heavy minerals were concentrated using the Wilfley table and heavy liquids. Magnetic minerals were then removed using an isodynamic Frantz separator. From the remaining zircon concentrate, grains were carefully handpicked under a binocular microscope, embedded in epoxy mounts and polished. They were imaged by cathodoluminescence (CL) using a Reliotron CL system available at the GeOHeLiS analytical platform (Univ. Rennes1). U-Pb analyses were carried out by in situ LA-ICP-MS at the Laboratoire Magmas et Volcans in Clermont-Ferrand, France. We used ablation spot diameters of $26 \mu \mathrm{m}$ with a repetition rate of 3 Hz. Data were corrected for $\mathrm{U}-\mathrm{Pb}$ fractionation and for the mass bias by standard bracketing with repeated measurements of the GJ1 zircon standard (Jackson et al., 2004). Data reduction was carried out with the GLITTER ${ }^{\circledR}$ software package developed by the Macquarie Research Ltd (van Achterbergh et al., 2001). In addition, the zircon standard 91500 (Wiedenbeck et al., 1995) was analyzed as an unknown (quality control) and yielded a concordia age of $1066.7 \pm 2.1$ Ma $(\operatorname{MSWD}=0.45, \mathrm{n}=10)$. Further information on the instrumentation and the analytical technique is detailed in Paquette et al. (2014), Poujol et al. (2017) and in supplementary Table 2. Ages and diagrams were generated using IsoplotR (Vermeesch, 2018).

\section{Petrologic, geochemical and geochronological characterization}

\section{Mineral composition}

Electron Microprobe (EMP) analyses were acquired on several samples (Table 1) in order to get a good representativity of the different facies and mineralogical assemblages found in both plutons (east and west lobes, core and border from the Lekkersmaak and the Willie samples). Plagioclase grains are common, with albite to oligoclase composition (maximum An15.1; Fig. 3a). Plagioclase grains show very little zoning, with only a decrease of $1-2 \%$ of the anorthite contents toward the edge. K-feldspar crystals (microcline in thin section), absent in the Willie sample and rare in the Lekkersmaak samples, are highly potassic (ca. Or 94-98; Fig. 3a). 
Most of the muscovite grains have a magmatic composition, falling in the primary, high-Ti field of Miller et al. (1981; Fig. 3b). Some samples have both magmatic and secondary muscovite in variable proportion. Garnet in sample MUR 09-67 is Mn-rich almandine with the global composition $\mathrm{Alm}_{66} \mathrm{Sps}_{29} \operatorname{Prp}_{5}$.

\section{Major and trace elements}

The chemical composition of the samples from the Lekkersmaak and the Willie plutons are presented in Table 2. Major elements are reported in Harker diagrams on Figure 4 together with a database of S-type plutons of various ages and locations (Bonin et al., 2020). In these diagrams, the Willie sample MUR 09-108 is indistinguishable from the Lekkersmaak ones and was consequently not labeled differently. Samples are silica rich $\left(\mathrm{SiO}_{2}\right.$ between 72.6 and $\left.75.8 \mathrm{wt} . \%\right)$ and lay on the evolved side of the peraluminous compositional trend. Samples are rich in alkalis $\left(\mathrm{Na}_{2} \mathrm{O}+\mathrm{K}_{2} \mathrm{O}=7.4\right.$ to 8.4 wt.\%) as most S-types granites. Samples MUR 09-61 and MUR 09-80 show a significant enrichment in $\mathrm{Na}_{2} \mathrm{O}$ and a correlative depletion in $\mathrm{K}_{2} \mathrm{O}$ (Fig.4), a feature which could be attributed to a post-magmatic, albitization-type alteration. Even if these two samples are excluded, the samples belong to the sodic-rich, potassic-poor S-type granites. As a whole, the granites have a moderately peraluminous character $(\mathrm{A} / \mathrm{CNK}=1.06$ to $1.13 ; \mathrm{A} / \mathrm{NK}=1.16$ to 1.24$)$, and plot in the felsic-peraluminous field of the B-A diagram (Villaseca et al., 1998) (Fig. 5).

Trace elements contents (such as $\mathrm{Nb}$, Th or $\mathrm{Rb}$ ) appear in the range expected for magmatic values (Fig. 4). With average $\mathrm{Rb}, \mathrm{Ba}$ and $\mathrm{Sr}$ of 185,557 and 266 respectively these granites are not particularly fractionated (Chappell, 1999). REE spider plots (Fig. 6) are reported as normalized to average Archean sediments (Taylor and McLennan, 1985), i.e. their potential source. This allows for an easier interpretations of any anomaly related to the melting process, rather than being the sum of all previous fractionation events (Moyen et al., submitted). In this view, a striking feature is the degree of HREE depletion achieved by some of the samples, together with a large negative Eu anomaly. Except for two samples (MUR-09-63 and -67), there is a good correlation between these two indicators (inset of figure), that, on the other hand, are not correlated to $\mathrm{SiO}_{2}$ or other differentiation indices. 


\section{U/Pb geochronology}

Six samples were selected for U-Pb geochronology. They are representative of the petrologic, mineralogical and chemical variability encountered in the plutons in terms of facies, muscovite-bearing or muscovite-free samples (whether they are primary or secondary muscovite) or anomalous chemical features (such as the more sodic sample MUR 09-80). This sampling covers most of the large intrusion (eastern and western lobes, border and core, as well as the Willie pluton) and allows to estimate the timing of the magmas emplacement as well as the duration of the pluton construction.

For each sample, the U-Pb zircon dataset is presented individually in Table 3. In general, zircon grains are prismatic. Cathodoluminescence imaging reveals that most of the grains are characterized by a bright “core" with well-defined oscillatory zoning (Fig. 7).

Five samples from the Lekkersmaak pluton (MUR 09-66, 09-109, 09-80, 09-72 and 09-64) have been selected for $\mathrm{U}-\mathrm{Pb}$ dating. A total of 66 analyses out of 58 zircon grains have been performed, either in the inner or in the outer part of the grains (Table 3).

The first four samples pluton (MUR 09-66, 09-109, 09-80 and 09-72) correspond to the mica-bearing type of granite. Zircon grains are prismatic and range in size from 60 to 200 microns (Fig. 7). They are characterized by magmatic zoning (Fig. 7) with the exception of two grains (Zr13, MUR 09-109 and Zr5, MUR 09-80) with the presence of large inherited cores (Fig. 7). Pb and U contents are variable (9-209 ppm and 13-293 ppm respectively) with highly variable $\mathrm{Th} / \mathrm{U}$ ratios ( 0.1 to 4 ; Table 3$)$. Fourty-two out of the 44 analyses yield a ${ }^{207} \mathrm{~Pb} /{ }^{206} \mathrm{~Pb}$ mean date of $2771 \pm 6 \mathrm{Ma}$ (Fig. 8A, MSWD=0.91). Among these analyses, seventeen concordant ones allow to calculate a concordia date (as of Ludwig, 1998) of $2771 \pm 2$ Ma (Fig. 8A, MSWD=1.4), that we consider as the emplacement age of the mica-bearing granite from the Lekkersmaak pluton. The two remaining analyses are concordant and yield ${ }^{207} \mathrm{~Pb} /{ }^{206} \mathrm{~Pb}$ apparent ages of $2899 \pm 18$ and 3098 \pm 18 Ma respectively. These old dates are consequently interpreted as inherited. They can be compared to the emplacement age of the Harmony granite (3091 \pm 5 Ma, Poujol and Robb, 1999) or the deposition of the volcano-sedimentary succession of the Weigel Formation (3087 \pm 21 Ma, Poujol et al., 1996) and the Maranda

granite (2901 \pm 20 Ma, Poujol et al., 1996) respectively, all these cropping out in the vicinity of the Lekkersmaak pluton. 
Twenty-two analyses were performed for the muscovite-free sample MUR 09-64 (Table 3). Zircon grains are prismatic and range in size from 60 to 150 microns. In cathodoluminescence they present concentric magmatic zoning (Fig. 7). $\mathrm{Pb}$ and $\mathrm{U}$ contents are variable (11-156ppm and 21-359ppm respectively) with fairly consistent magmatic $\mathrm{Th} / \mathrm{U}$ ratios between 0.3 and 0.9 . Plotted in a concordia diagram, they all plot in a concordant to sub-concordant position (Fig. 8B) and yield a concordia date of $2734 \pm 11 \mathrm{Ma}(\mathrm{MSWD}=1.9)$ for the fourteen data that are concordant within error. The mean ${ }^{207} \mathrm{~Pb} /{ }^{206} \mathrm{~Pb}$ date for all the analyses is equivalent within error at $2741 \pm 9 \mathrm{Ma}(\mathrm{MSWD}=1.2 ; \mathrm{N}=22)$. This age of ca. $2.74 \mathrm{Ga}$, that we interpret as the emplacement age for the muscovite-free granite, can be compared to the U-Pb zircon age of $2690 \pm 65$ Ma previously published by Burger and Walraven (1979) for a sample from the Lekkersmaak pluton.

These two ages (ca 2.77 and $2.74 \mathrm{Ga}$ ) obtained for the Lekkersmaak pluton are both younger than the age of $2795 \pm 8$ Ma published by Zeh et al. (2009) for sample MB1, collected on the southern edge of the Lekkersmaak pluton, although no indications are provided regarding its petrology and/or chemistry.

The last sample, MUR 09-108, corresponds to the Willie granite. Zircon grains are prismatic with sizes bracketed between 50 and 120 microns and are characterized by magmatic zoning (Fig. 7). Their $\mathrm{Pb}$ and $\mathrm{U}$ contents are variable (9-119 and 14-166 ppm respectively), while their U/Th ratios are consistent with a magmatic origin with values between 0.4 and 1 (Table 3). Out of 18 analyses, a group of 16 concordant ones (Fig. 8C) yields a concordia date of $2816 \pm 9 \mathrm{Ma}(\mathrm{MSWD}=1.7)$. Two analyses from the same grain yield a ${ }^{207} \mathrm{~Pb} /{ }^{206} \mathrm{~Pb}$ date of ca $3.25 \mathrm{Ga}$ while the last grain is discordant with a ${ }^{207} \mathrm{~Pb} /{ }^{206} \mathrm{~Pb}$ date of $2820 \pm 21 \mathrm{Ma}$. This date of $2816 \pm 9 \mathrm{Ma}$, is interpreted as the emplacement age of the Willie granite. This age is consistent, although more precise, with an ID-TIMS U-Pb age obtained on single zircon grains at $2820 \pm 38 \mathrm{Ma}$ (Poujol, 2001). The date of ca $3.25 \mathrm{Ga}$ is therefore interpreted as inherited. This date is within error with the age of the French Bob Mine granite, located to the South of the MGB, dated at $3228 \pm 12 \mathrm{Ma}$ (U-Pb by ID-TIMS; Poujol et al., 1996).

One striking feature is the quasi-absence of inheritance shown by the zircon age data spectrum, as only 3 older dates were found out of 62 analyses (3.25, 3.1 and $2.9 \mathrm{Ga})$. S-type granites are known to typically contain a substantial fraction of inheritance representative of the heterogeneity of the source (see review in Villaros et al., 2012 for example). We can however point out that in the case of the S-type granite from Wyoming (Grace et al., 2006) or from the clasts from the Barberton greenstone belt (Sanchez-Garrido et al., 2011), such inheritance is also absent in the analyzed zircon grains. Several explanations could be proposed at 
this stage. An explanation could be that the zircon dated in this study crystallized very late or that the $\mathrm{Zr}$ saturation level was very high (such as the one usually encountered in I-type magmas). Alternatively, the source of this S-type granite could have contained very little zircon grains to start with. However, we can immediately discard the possibility that the source was mostly mafic as it has been demonstrated that a source with more than $10 \%$ of mafic material leads to the production of a metaluminous magma (Collins, 1998).

\section{Radiogenic isotopes}

Isotopic analyses of the $\mathrm{Sm}-\mathrm{Nd}$ and $\mathrm{Rb}-\mathrm{Sr}$ systems are presented in Table 4, and the $\mathrm{U}-\mathrm{Pb}$ ages are used to calculate the $\mathrm{I}_{\mathrm{Sr}}$ and $\varepsilon_{\mathrm{Nd}}$ parameters. For the Lekkersmaak granite, the $\varepsilon_{\mathrm{Nd}}$ values are near-chondritic at the time of crystallization (Fig. 9) with $\mathrm{T}_{\mathrm{DM}}$ ages ranging from 2880 to $3022 \mathrm{Ma}$ (with the exception of sample MUR 09-80 which has a very unradiogenic signature, $\varepsilon_{\mathrm{Nd}}=-18.1$; Fig. 9). $\mathrm{I}_{\mathrm{Sr}}$ show variable values from 0.6819 to 0.7019 (Table 4), most of them being consequently below the BABI value of 0.699 (MUR 09-60, 61, 67,72, $109,8 \mathrm{a})$. For the Willie granite, the $\varepsilon_{\mathrm{Nd}}$ (calculated at $2.82 \mathrm{Ga}$ ) is -0.74 and the TDM is $3050 \mathrm{Ma}$. Therefore, these values are comparable with the ones found for Lekkersmaak (Fig. 9). Here again, the $\mathrm{I}_{\mathrm{Sr}}$ is abnormal at 0.6985 .

Such abnormally low $\mathrm{I}_{\mathrm{Sr}}$ values for both the Lekkersmaak and Willie plutons indicate that the $\mathrm{Rb}-\mathrm{Sr}$ system has been disturbed since the crystallization of these granites leading to Rb gain and/or Sr loss. We can notice at this stage that Barton (1984) produced biotite $\mathrm{Rb} / \mathrm{Sr}$ ages around $1.3 \mathrm{Ga}$.

\section{Stable isotope characterization}

The oxygen isotope composition of whole rocks displays a narrow range $\left(\delta^{18} \mathrm{O}\right.$ values from 8.2 to $9.2 \%$ ). These signatures are expected for granitic rocks (Taylor and Hugh, 1978) but are actually low for S-type granites that generally have $\delta^{18} \mathrm{O}$ values above $10 \%$, such as in Himalayan leucogranites (France-Lanord et al., 1988) and in Australian batholiths (O’Neil et al., 1977). In detail (Fig. 10), there is a tendency for the most evolved samples (highest $\mathrm{SiO}_{2}$ content, lowest $\mathrm{Fe}+\mathrm{Mg}+\mathrm{Mn}+\mathrm{Ti}$ content) to have the highest $\delta^{18} \mathrm{O}$ value, and for the less evolved samples to have the lowest $\delta^{18} \mathrm{O}$ value. This relationship may either reflect modal effects (i.e. samples enriched in high- $\delta^{18} \mathrm{O}$ quartz display the highest $\delta^{18} \mathrm{O}$ value, samples enriched in low- $\delta^{18} \mathrm{O}$ micas display the lowest $\delta^{18} \mathrm{O}$ value) or the fact that the samples actually underwent different degrees of differentiation (e.g. Tartèse and Boulvais, 2010). Regardless of the exact explanation, these relationships are 
indicative of the magmatic history rather than of some post-magmatic alteration as was recorded by sample MUR 09-80.

\section{Discussion}

\section{S-type character of the Lekkersmaak pluton}

S-types plutons are rare in Archean terranes. Therefore, some unusual geologic conditions (source of the granite, PT conditions of melting) must account for the production of the Lekkersmaak pluton. Before constraining these conditions, we need to discuss the meaning of the peraluminous signature of Lekkersmaak and Willie granites.

First of all, in order to ascertain that this signature is a primary, magmatic signature, we first have to evaluate the level of chemical alteration of the samples. In the region and in particular in the Antimony Line, albitization is the main form of granitoid alteration and is broadly coeval with Lekkersmaak emplacement at ca. 2.8 Ga (Jaguin et al., 2013). As an example, sample MUR 09-80 and to a lesser extent sample MUR 09-61 display several compositional anomalies in $\mathrm{Na}_{2} \mathrm{O}$ and $\mathrm{K}_{2} \mathrm{O}$ contents, $\mathrm{Na}_{2} \mathrm{O} / \mathrm{K}_{2} \mathrm{O}$ ratio (Fig. 4), and $\mathrm{Rb}-\mathrm{Sr}$ and Sm-Nd isotope compositions (Table 4). Those features are not associated with any special mineralogical or textural features. It rather indicates a discrete albitization. Once these two samples are excluded, the $\mathrm{Na}, \mathrm{Ca}$ and $\mathrm{K}$ contents of other samples are very homogeneous, which argues for an unaltered signature in alkalies and ensures the petrological significance of the $\mathrm{A} / \mathrm{CNK}$ (1.06 to 1.13) and A/NK (1.16 to 1.24) ratios.

From a mineralogical point of view, we targeted white mica because it is a widespread alteration mineral in igneous rocks as well as a magmatic mineralogical indicator of high-aluminum magma. Figure $3 \mathrm{~b}$ shows that most of muscovite grains fall within the primary magmatic field. Moreover, it is possible to evaluate texturally the primary or secondary origin of muscovite. Textural criteria of secondary muscovite origin are small grain size, association with secondary minerals (epidote, titanite; Fig. 2e) instead of magmatic minerals (biotite, zircon; Fig. 2d) and occurrence in close association with dissolution figures, sheared zones or recrystallized zones. These mineralogical characteristics correlate well with chemical analyses, i.e., texturally identified secondary-type muscovites fall within the field of secondary muscovite in figure $3 \mathrm{~b}$. From that, we infer that MUR 09-60, MUR 09-80, MUR 09-81 and MUR 8a very likely bear magmatic muscovite (in addition to secondary muscovite) but foliated sample MUR 09-72 is still doubtful regarding that point. 
We thus conclude on the basis of mineralogical and geochemical characteristics that the Lekkersmaak pluton is a $\mathrm{Mg}-\mathrm{Fe}-\mathrm{Ca}$ poor and moderately peraluminous granite.

The second issue to consider is whether these granites can be the result of fractionation of a more common magma type (TTG or "biotite granites" such as in the nearby Turfloop batholith; (Henderson et al., 2000; Laurent et al., 2014; Laurent et al., 2013a)). We rule out this hypothesis for several reasons. (i) Although the REE patterns do display the large Eu anomaly typical for fractionated granites (Chappell, 1999), the rest of their trace element compositions (in particular the $\mathrm{Rb}-\mathrm{Ba}-\mathrm{Sr}$ systematics) is not consistent with this model. (ii) The granites contain some inherited zircon cores, meaning that the magma never reached a temperature above the zircon saturation values (Miller et al., 2003). Here the zircon saturation values are on average 756 ${ }^{\circ} \mathrm{C}$ (Watson and Harrison, 1983), or $707^{\circ} \mathrm{C}$ (Boehnke et al., 2013), a value that is consistent with rather cold granites, that did not experience a high-T evolution. (iii) The depletion in HREE is consistent with melts in equilibrium with garnet, which would require deep (ca. $10 \mathrm{kbar}$ ) fractionation of a TTG magma (Alonso-Perez et al., 2003; Marxer and Ulmer, 2019): not an impossible value, but surely an unusual one away from magmatic arcs.

Thus, we conclude that the most likely interpretation of the peraluminous signature of the Lekkersmaak and Willie granites is that they originate from partial melting of sediments, and represent Msbearing S-type granites.

\section{Petrogenesis of the Lekkersmaak pluton}

The occurrence of such a S-type pluton requires two unusual (in the Archean) conditions: accumulation of a sizeable aluminous sedimentary source and, subsequently, a tectonic context that drives these sediments to sufficient depth to trigger partial melting. Here we comment on the plausible scenario permitting such conditions.

Nature of the source and conditions of formation of the Lekkersmaak pluton

Although there is little doubt on the sedimentary nature of the source, the studied plutons differ from classical S-type plutons on several points. First, they are on average, more sodic and less potassic than typical S-type granites, which is consistent with the overall low anorthite content of the plagioclase. Secondly, their high $(\mathrm{La} / \mathrm{Yb})_{\mathrm{N}}$ ratio is more similar to Archean TTG granitoids (> 30) rather than common S-types granites or post- 
Archean granitoids (most S-types in the database used are post-Archean); nevertheless, the measured Eu negative anomaly resembles those of typical S-granites. Finally, the $\delta^{18} \mathrm{O}$ value of whole rocks is low and the dated zircon grains show only rare inheritance.

The peraluminous chemistry implies melting by mica breakdown, and thus of a mica-rich (formerly clay) component in the source. The sodic chemistry suggest an immature, plagioclase-rich component, most likely derived from erosion of (plagioclase-rich) TTG rocks. Archean detrital sediments, such as those in Barberton (Byerly et al., 2018), the Witwatersrand supergroup (Mc Carthy, 2006), or the successions in the Pilbara craton (Mc Lennan et al., 1983) provide us with a reasonable image of what the source could have been: a greywacke-shale (or mudstone), turbidite-like sequence of immature clastic sediments.

We have only limited constraints on the conditions of melting. The variously depleted HREE patterns suggest the presence of residual garnet. Garnet is stable, during metasediment melting, at pressures lower than what would be required in a fractionating metaluminous magma: for instance, pseudosection modelling in the micaschists of the La France formation in the Murchison Belt (Block et al., 2013) indicates that garnet is stable at pressures as low as 3-4 kbar in these compositions. The leucocratic compositions of the granites, reminiscent of the very felsic Himalayan leucogranites (Harris et al., 1986), is consistent with melting through muscovite dehydration-melting reactions, i.e at temperatures not exceeding $750{ }^{\circ} \mathrm{C}$ (Barbey et al., 2015; Clemens and Vielzeuf, 1987; Villaros et al., 2018), in good agreement by the presence of (rare) zircon inheritance and low $\mathrm{Zr}$ saturation temperatures. These various lines of evidence support the fact that these rocks have formed by partial melting of metasediments at mid-crustal upper-amphibolite facies conditions.

\section{Regional correlations}

The rocks that melted, by definition, do not exist anymore but we can nevertheless compare the characteristics of the source, as we have outlined it, with regionally existing units. Here, we need a reasonably thick sequence of immature (plagioclase-rich) metasediments, probably with clay-rich intercalations, and of course deposited prior to ca. $2.82 \mathrm{Ga}$. Furthermore, the Lekkersmaak granites have chondritic to slightly sub-chondritic Nd isotopic signatures, and low $\delta^{18} \mathrm{O}$ of 8 to 10 that the expected source must match. 
The largest such sequence preserved in the Kaapvaal Craton is the Witwatersrand basin, deposited after 3.05-2.97 $\mathrm{Ga}$ and prior to $2.74 \mathrm{Ga}$. In addition to being older than the Lekkersmaak pluton, the Witwatersrand sediments display Sm-Nd signatures consistent with the signatures found for the Lekkersmaak pluton $\left(\varepsilon_{\mathrm{Nd}}=-3\right.$ to 0 at $2.8 \mathrm{Ga}, \mathrm{T}_{\mathrm{DM}}=3.35-3.12 \mathrm{Ga}$; Jahn and Condie, 1995). Besides, the $\delta^{18} \mathrm{O}$ values of the sediments $\left(\delta^{18} \mathrm{O}\right.$ between 8 and 13\%) show a tendency to become lower as the grain size gets smaller (Barton et al., 1992; Vennemann et al., 1992; 1996; Jaguin et al., 2010), so that shales are expected to have quite low $\delta^{18} \mathrm{O}$ signatures, around $8 \%$ or slightly below. As a source, it would impose a comparable low $\delta^{18} \mathrm{O}$ value of any melt produced near $8 \%$ or slightly above, comparable to the one actually measured in the Lekkersmaak samples. However, at ca. 2.82-2.77 Ga the Witwatersrand basin was still being formed. It is, furthermore, situated $300 \mathrm{~km}$ away, and in an intra-cratonic setting offering little prospect for the required burial and metamorphism.

In the core of the craton, the Barberton Granite-Greenstone terrain includes some preserved sedimentary units (e.g. the Fig Tree and Moodies group; Byerly and Lowe, 2018) that petrologically could be an appropriate source. Similar material forms unquantified but probably large volumes of the middle crust of the same area, as observed in the Ancient Gneiss Complex of eSwatini (Swaziland) (Kröner et al., 2019), where it is indeed observed to melt and form S-type granites (Taylor et al., 2010). Although this provides a worthwhile example of how S-type granites can be formed in the Archaean, this specific material is unlikely to be the actual source for the Lekkersmaak granitoids: it was deposited in the meso-Archaean (ca. 3.2 Ga), and was at 2.8 Ga too isotopically evolved to be a plausible source (Toulkeridis et al., 1999; Zeh et al., 2013). In any case, the core of the craton was stabilized at ca. $3.1 \mathrm{Ga}$, as attested by the deposition of the Dominion group on top of it at ca. $3.08 \mathrm{Ga}$ onwards (Marsh, 2006) and rocks of this region are therefore hardly a suitable source.

More promising candidates, then, would be rocks found in the then more active zone occurring at the Northern edge of the cratonic core - i.e., at or near the TML. Although they occur only as small volumes, metasediments are found both in the Pietersburg (de Wit et al., 1993) and the Murchison Greenstone Belts. The Murchison Belt exposes aluminous sedimentary rocks (now micaschists) immediately to the north of the Lekkersmaak suite, namely the La France Formation (Fig. 1b). These staurolite-bearing micaschists as well as the occurrence of quartz-kyanite veins evidence medium pressure, medium temperature metamorphism in the belt. Block et al. (2013) estimated upper amphibolic facies conditions for the La France Formation peak 
metamorphism (ca. 8-9 kbar, $600-650^{\circ} \mathrm{C}$ ) and then decompression toward ca. 5-6 kbar, $580^{\circ} \mathrm{C}$. These are metamorphic conditions comparable to Phanerozoic geothermal gradients which commonly produce partial melting at depth. It is then predictable that, if sediments were buried at deeper levels, the immediate underlying structural level would have experienced partial melting P-T conditions. We lack comprehensive isotopic constrains on these rocks. In the Pietersburg Greenstone Belt, Zeh and Gerdes (2012) report slightly superchondritic $\mathrm{Hf}$ isotopic values in zircon at ca. $2.9 \mathrm{Ga}$ - such values would yield slightly sub-chondritic compositions at $2.8 \mathrm{Ga}$, so probably appropriate compositions. One metapelite from the Murchison Belt (presumably taken from the La France formation), analyzed by Kreissig et al. (2000), has recalculated $\varepsilon_{\mathrm{Nd}}(2800$ Ma) of +0.05 , again a realistic value for the source of the Lekkersmaak granitoids. Despite their small presentday volumes, these rocks have the appropriate nature and isotopic composition, they occur in the right place and they have demonstrably been metamorphosed along geothermal gradients consistent with burial to melting conditions.

The Lekkersmaak pluton is occupies ca. $450 \mathrm{~km}^{2}$. Assuming a laccolith shape with a thickness versus length ratio of $1: 10$ and a rather high melting rate of $30 \%$, the metasedimentary package involved in the melting must have represented a volume of about $5700 \mathrm{~km}^{3}$. It comes from this crude estimate that the genesis of the pluton required the burial of a quantity of sediments much exceeding the present-day volumes (the La France formation, for instance, occupies a restricted area no larger than a few square kilometers). We therefore have to postulate a fairly active tectonic environment allowing the generation and disposal of significant amounts of sediments. At the same time, S-type granites such as Lekkersmaak are only a minor component of the ca. 2.9-2.7 Ga magmatism of this area (the region between the TML and the Hout River Shear Zone occupies nearly $20,000 \mathrm{~km}^{2}$, most of which made of granitoids), so this process was only one component of a larger system. 


\section{A protracted magmatism}

The Willie granite has been dated at $2816 \pm 9 \mathrm{Ma}$ and is chemically identical to the Lekkersmaak pluton. The Lekkersmaak pluton was emplaced $2771 \pm 2$ Ma ago whereas sample MUR 09-64, devoid of S-type features as it is muscovite-free, aluminum poor $(11.8 \mathrm{wt} . \%)$, with a strong positive europium anomaly $(\mathrm{Eu} / \mathrm{Eu} *=2.08)$, was emplaced $2734 \pm 11 \mathrm{Ma}$ ago. In summary, S-Type magmatism in the area occurred twice, at $2.82 \mathrm{Ga}$ and then $40 \mathrm{Myr}$ later at $2.77 \mathrm{Ga}$, involving comparable metasedimentary sources and conditions of partial melting.

For the Lekkersmaak pluton itself, if we take into account the age of $2795 \pm 8$ Ma published by Zeh et al. (2009) together with the age of $2771 \pm 2$ Ma obtained in this study, the building of the pluton took a minimum of 14 Myr. According to de Beer (1982), the Lekkersmaak pluton presents a maximum thickness of $1 \mathrm{~km}$, therefore, if we consider that half of the pluton was eroded away, we can estimate its initial volume at a minimum of $900 \mathrm{~km}^{3}$. These results are in a good agreement with the duration of pluton building according to de Saint Blanquat et al. (2011). However, if we consider that the muscovite-free sample MUR 09-64 is part of the Lekkersmaak pluton, the duration for the construction of the pluton increase to a minimum of $42 \mathrm{Ma}$, an anomalous long time compared to the size of the pluton (de Saint Blanquat et al., 2011). Therefore, we consider that the magmatic activity south of the MGB was episodic as already discussed by Poujol (2001).

However, the similarities both in term of geochemistry and location shared by the two plutons (Lekkersmaak and Willie) seem to demonstrate that comparable petrogenetic conditions prevailed for both. The same context was therefore either maintained for ca. $40 \mathrm{Ma}$ or repeated during two separate events. It is doubtful that an uninterrupted melting would have been maintained (see above), producing only two emplacement episodes. It is also doubtful that the same succession of events happened twice. A composite solution is to propose that sub-solidus conditions were maintained for at least $40 \mathrm{Ma}$ but reached the threshold of partial melting only twice. At the same time, a source out of which an S-type melt has been extracted is unlikely to melt again -and if it does, it is unable to generate S-type melts again. This implies that the source region of the successive granites were made of similar rocks, but were physically (and spatially) distinct. Therefore, the similar geochemistry and location suggest that an appropriate source met the appropriate conditions in a dynamic system rather than in a static one, with fertile sediments being supplied to the system. Finally, this protracted magmatic activity echoes the long lasting tectonic, metamorphic and granodioritic 
magmatism history in the Murchison Belt. The geologic history of the belt as a whole may be related to a slow continuous evolution of the area marked by activity pulses (melting, extraction) at different times.

More globally, there is ample evidence for protracted granitic magmatism North of the ThabazimbiMurchison Lineament (TML) during this period. In fact, granites occur nearly continuously during the ca. 150 Myr interval from ca. 2900 to 2750 Ma (Laurent et al., 2013b; Laurent and Zeh, 2015; Laurent et al., 2019; Vézinet et al., 2018) in this region, and collectively record the melting of increasingly "crustal" sources with more and more potassic compositions. Muscovite-bearing phases have been described in parts of the Turfloop batholith (the Meinhardtkraal pluton), although their chemistry has not been described yet (Henderson et al., 2000). In this light, the Lekkersmakk and Willie plutons are not unexpected; they merely represent an endmember of the crustal melting process that affected the bulk of the Northern Kaapvaal Craton at that time, yielding a range of granitoids reflecting the sources involved.

\section{Tectonic conditions}

The Murchison belt is part of the Thabazimbi-Murchison Lineament (TML), the main geophysical boundary between the ancient core of the craton and the younger "mobile belt" to the North (Poujol et al., 2003). South of the TML, the post-3.1 Ga geological activity seems to be restricted to the emplacement of dykes and upper level granites and the deposition of supracrustal sequences. In contrast, the northern domain underwent pervasive melting and deformation culminating in the ca. 2.72 Ga "Limpopo orogeny" (Van Reenen et al., 2019). In between, the Murchison area is the only place in the region where distinctly juvenile $(\varepsilon H f=$ +5) magmatism occurred at ca. $2.96 \mathrm{Ga}$ (Laurent et al., 2019; Zeh et al., 2013).

The Murchison Belt has a tectonic history from 3.09 to 2.78 Ga. It involves first the deposition of a volcano-sedimentary sequence (Weigel and Mulati formations, then Rooiwater complex), capped by the detrital sediments of the La France formation. This is consistent with the remnants of a basin developing at the edge of the recently stabilized (Moyen et al., submitted) Kaapvaal Craton core, separating the main Kaapvaal Craton with the small gneissic fragments that would eventually form the Pietersburg block (Laurent et al., 2019; Zeh et al., 2009) and accrete over the core of the Kaapvaal Craton. Presumably, this basin included a significant sedimentary component, fed by detritus from the older TTG basement of the cratonic core to the south, but also from the juvenile components to the immediate North, reaching a near-chondritic average composition. Similar processes of mixing and homogeneization in basins is described in more recent systems, 
for instance accretionary orogens such as the remains of the Cadomian (late Panafrican) belt of Western Europe (Couzinié et al., 2017). Although the analogy should not be stretched too far, we postulate that, similar to modern accretionary orogens, the edge of the Kaapvaal craton at ca. 2.9-2.7 Ga was marked by rapid opening and closing of volcano-sedimentary basins. In these basins, the (volumetrically minor) sedimentary component was a mixture of old crustal material and young, juvenile detritus from the associated mafic activity. Closure of the basins resulted in melting of all available lithologies: preferentially whatever sediments were available, but also the hydrated mafic rocks (forming TTGs), and possibly locally the older TTG basement itself (forming "ordinary" potassic granitoids), collectively accounting for the diversity of the ca. $2.9-2.7$ Ga magmatism at and near Murchison (Vézinet et al., 2018; Laurent et al. 2019).

The processes leading to the closure of the basin are enigmatic. Strain patterns show that they include a component of sagduction, enhanced by gravity forces within the greenstone belt (Jaguin et al., 2012), that dominates the present-day map pattern. The duration of the crustal magmatism on the other hand, and the production of crustal melts for $>150 \mathrm{Myr}$, shows that tectonic activity was not restricted to one rapid, shortlived crustal overturn but rather developed over a long period involving numerous heating and melting events, perhaps reflecting small strain variations in a long-lived strain field (Gapais et al., 2005).

Although the Kaapvaal Craton accumulated Meso- to Neo-Archean sedimentary sequences (3.05-2.97, $3.2 \mathrm{Ga}$ ) and in various contexts (Witwatersrand basin, Barberton, Murchison and Pietersburg Greenstone Belts), burial and melting of sedimentary rocks are so far restricted to the northeast of the Kaapvaal Craton (and Swaziland, now Eswatini) where cratonisation was not yet achieved. Thus, the formation of the Murchison S-type granites reflects the very peculiar, long-lived deformation that occurred at the northern edge of the stable Kaapaal cratonic core, marked by opening and closing of basins and deformation (mainly sagduction) of a weak and hot crust, buttressed by the nearby cratonic core.

\section{Conclusions}

Our main conclusions are as follows:

- The Lekkersmaak granite is a S-type biotite-muscovite-garnet bearing granite, except that it is sodic in nature and has strongly fractionated REE pattern. It also presents near-chondritic $\varepsilon N d$ values at the time of its crystallization. 
- It formed by the melting of a large immature sedimentary package, eroded from the Kaapvaal Craton and deposited after ca. $3.10 \mathrm{Ga}$.

- The Lekkersmaak S-type granite was emplaced $2771 \pm 2 \mathrm{Ma}$ ago as a single large intrusion.

- The Willie intrusion, a small S-type body located in the western part of the Lekkersmaak granite with which it shares many geochemical characteristics, crystallized earlier at $2816 \pm 9 \mathrm{Ma}$.

- Therefore, S-Type magmatism in the area occurred twice, at $2.82 \mathrm{Ga}$ and then $40 \mathrm{Ma}$ later at $2.77 \mathrm{Ga}$, involving comparable metasedimentary sources and conditions of partial melting.

- A sample from the Lekkersmaak, devoided of S-type features as it is muscovite-free, aluminum poor was emplaced $2734 \pm 11$ Ma ago.

- Partial melting was triggered by the burying of sediments during the evolved tectono-metamorphic stages of the belt.

\section{Acknowledgements}

MP would like to warmly thank Carl Anhaeusser for introducing him to the joys of Archean geology and metallogeny when he was a PHD student. This study is based on the work carried out by J.J. for her PhD degree and was supported by the 2010 CNRS/INSU research grant to M.P. J.-L. Devidal and V. Bosse allowed access to the electronic microprobe at the Laboratoire Magmas et Volcans, Clermont-Ferrand (France). D. Vilbert is thanked for his contribution during the radiogenic isotope analyses. P. Barbey and S. Prevec are thanked for providing detailed and insightful reviews and F.M. Meyer for his efficient editorial handling. JFM's stay at Monash is supported by the Australian Research Council grant FL160100168. 


\section{References}

Alonso-Perez, R., Ulmer, P., Müntener, O., Thompson, A.B., 2003. Role of garnet fractionation in H2O undersaturated andesite liquids at high pressure. Lithos 73, S116.

Anhaeusser, C.R., 2006. A reevaluation of Archean intracratonic terrane boundaries on the Kaapvaal Craton, South Africa: Collisional suture zones? In Reimold, W.U., and Gibson, R.L., Processes on the Early Earth: Geological Society of America Special Paper 405, 193-210.

Barbey, P., Villaros, A., Marignac, C., Montel, J.M., 2015. Multiphase melting, magma emplacement and P-T-time path in late-collisional context: the Velay example (Massif Central, France). Bulletin de la Société Géologique de France 186, 93-116.

Barton, J.M., 1984. Timing of Ore Emplacement and Deformation, Murchison and Sutherland Greenstone Belts, Kaapvaal Craton. In: R.P. Foster (editor), 1984. Gold, 1982: The Geology, Geochemistry and Genesis of Gold Deposits. Balkema, Rotterdam, 1, 629-644.

Barton, J. M., Wenner, D. B. and Hallbauer, D. K., 1992. Oxygen isotopic study of the nature and provenance of large quartz and chert clasts in gold-bearing conglomerates of South Africa. Geology, 20, 1123-1126.

Bédard, L.P. and Ludden, J.N., 1997. Nd-isotope evolution of Archean plutonic rocks in southeastern Superior Province. Canadian Journal of Earth Sciences, 34, 286-298.

Block, S., Moyen, J.-F., Zeh, A., Poujol, M., Jaguin, J. and Paquette, J.-L., 2013. The Murchison Greenstone Belt, South Africa: Accreted slivers with contrasting metamorphic conditions. Precambrian Research, 227, $77-98$.

Boehnke, P., Watson, E.B., Trail, D., Harrison, T.M., Schmitt, A.K., 2013. Zircon saturation re-revisited. Chemical Geology 351, 324-334.

Bonin, B., Janousek, V. and Moyen, J.-F., 2020. Chemical variation, modal composition and classification of granitoids. In: Janousek, V., Bonin, B., Collins, W.J., Farina, F. \& Bowden, P. (eds) Post-Archean Granitic Rocks: Petrogenetic Processes and Tectonic Environments. Geological Society of London, 491, 9-51.

Bourne, J. and Danis, D., 1987. A proposed model for the formation of reversely zoned plutons based on a study of the Lacorne Complex, Superior Province, Quebec. Canadian Journal of Earth Sciences, 24, 2506-2520.

Brandl, G., 1986. The geology of the Pietersburg area. Explanation Sheet 2328, Geological Survey of South Africa, 43pp. 
Brandl, G., Jaeckel, P. and Kröner, A., 1996. Single zircon age for the felsic Rubbervale Formation, Murchison Greenstone Belt, South Africa. South African Journal of Geology, 99, 229-234.

Bucholz, C.E. and Spencer, C.J., 2019. Strongly Peraluminous Granites across the Archean-Proterozoic Transition. Journal of Petrology 60,1299-1348.

Burger A.J. and Walraven, F., 1979. Summary of age determinations carried out during the period April 1977 to March 1978. Annal of Geological Survey of South Africa, 12, 209-218.

Byerly, G., Lowe, D. and Heubeck, C., 2018. Geologic evolution of the Barberton Greenstone Belt-a unique record of crustal development, surface processes, and early life 3.55 to $3.20 \mathrm{Ga}$. Earth's oldest rocks, 2nd edn. Elsevier, Berlin.

Carignan J., Hild, P., Mevelle, G., Morel, J. and Yeghicheyan, D., 2001. Routine Analyses of Trace Elements in Geolgical Samples using Flow Injection and Low Pressure On-Line Liquid Chromatography Couples to ICPMS: A Study of Geochemical Reference Materials BR, DR-N, UB-N, AN-G and GH. Geostandards Newsletter, 25, 187-198.

Cawood, P.A., Hawkesworth, C.J., Pisarevsky, S.A., Dhuime, B., Capitanio, F.A., Nebel, O., 2018. Geological archive of the onset of plate tectonics. Philosophical Transactions of the Royal Society A: Mathematical, Physical and Engineering Sciences 376, 20170405.

Chappell, B.W., 1984. Source rocks of I- and S-type granites in the Lachlan Fold Belt, southeastern Australia. Royal Society of London Philosophical Transactions series A 310, 693-707.

Chappell, B., 1999. Aluminium saturation in I-and S-type granites and the characterization of fractionated haplogranites. Lithos 46, 535-551.

Clayton, R.N. and Mayeda, T.K., 1963. The use of bromine pentafluoride in the extraction of oxygen from oxides and silicates for isotopic analysis. Geochimica et Cosmochimica Acta, 27, 48-52.

Clemens, J.D. and Vielzeuf, D., 1987. Constraints on melting and magma production in the crust. Earth and Planetary Science Letters, 86, 287-306.

Clemens, J.D., 2003. S-type granitic magmas-petrogenetic issues, models and evidence. Earth-Science Reviews, 61, 1-18.

Collins W.J., 1998. Evaluation of petrogenetic models for Lachlan fold belt granitoids: implications for crustal architecture and tectonic models. Australian Journal of Earth Sciences, 45, 483-500 
Couzinié, S., Laurent, O., Poujol, M., Mintrone, M., Chelle-Michou, C., Moyen, J.F., Bouilhol, P., Vézinet, A., et al., 2017. Cadomian S-type granites as basement rocks of the Variscan belt (Massif Central, France): Implications for the crustal evolution of the north Gondwana margin. Lithos, 286-287, 16-34,

Day, W.C. and Weiblen, P.W., 1986. Origin of late Archean granite: geochemical evidence from the Vermilion Granitic Complex of northern Minnesota. Contributions to Mineralogy and Petrology, 93, 283-296.

de Beer, J.H., 1982. A geophysical study of the Murchison greenstone belt, South Africa. Revista Brasileira de Geosciencias, 12, 105-112.

de Beer, J.H., Stettler, E.H., Duvenhage, A.W.A., Joubert, S.J. and De Raath, C.J., 1984. Gravity and geoelectrical studies of the Murchison greenstone belt, South Africa. South African Journal of Geology, 87, 347-359.

de Wit, M.J., Roering, C., Hart, R.J., Armstrong, R.A., De Ronde, C.E.J., Green, R.W.E., Tredoux, M., Pederby, E. and Hart, R.A., 1992. Formation of an Archaean Continent. Nature, 357, 553-562.

De Wit, M.J., Armstrong, R.A., Kamo, S.L. and Erlank, A.J., 1993. Gold-bearing sediments in the Pietersburg greenstone belt: age equivalents of the Witswatersrand supergroup sediments, South Africa. Economic Geology, 88, 1242--1252.

de Saint Blanquat M., Horsman, E., Habert, G., Morgan, S., Vanderhaeghe, O., Law, R. and Tikoff, B., 2011. Multiscale magmatic cyclicity, duration of pluton construction, and the paradoxical relationship between tectonism and plutonism in continental arcs. Tectonophysics, 50, 20-33.

Du Plessis, C.P., 1991, Tectonics along the Thabazimbi-Murchison Lineament: Ph.D. thesis: Johannesburg, University of the Witwatersrand, $307 \mathrm{p}$.

Dhoundial, D.P., Paul., D.K., Sarkar, A., Trivedi, J.R., Gopalan, K. and Potts, P.J., 1987. Geochronology and geochemistry of Precambrian granitic rocks of Goa, SW India. Precambrian Research, 36 287-302.

Ducharme, Y., Stevenson, R.K. and Machado, N., 1997. Sm-Nd geochemistry and U-Pb geochronology of the Preissac and Lamotte leucogranites, Abitibi Subprovince. Canadian Journal of Earth Sciences, 34, 10591071.

Evensen, N.H., Hamilton, P.J. and O'Nions, R.K. 1978. Rare earth abundances in chondrite meteorites. Geochimica Cosmochimica Acta, 42, 1199-1212. 
Feng, R. and Kerrich, R., 1992. Geochemical evolution of granitoids from the Archean Abitibi Southern Volcanic Zone and the Pontiac subprovince, Superior Province, Canada: Implications for tectonic history and source regions. Chemical Geology, 98, 23-70.

France-Lanord, C., Sheppard, S.M.F. and Fort, P.L., 1988. Hydrogen and oxygen isotope variations in the high Himalaya peraluminous Manaslu leucogranite: Evidence for heterogeneous sedimentary source. Geochimica et Cosmochimica Acta, 52, 513-526.

Fripp, R.E.P., Van Nierop, D.A., Callow, M.J., Lilly, P.A., 1980. Deformation in part of the Archaean Kaapvaal Craton, South Africa. Precambrian Research, 13, 241-251.

Gapais, D., Potrel, A., Machado, N., Hallot, E., 2005. Kinematics of long-lasting Paleoproterozoic transpression within the Thompson Nickel Belt, Manitoba, Canada. Tectonics 24, TC3002.

Gapais, D., Jaguin, J., Cagnard, F. and Boulvais, P., 2014. Pop-down tectonics, fluid channelling and ore deposits within ancient hot orogens. Tectonophysics 618, 102-106.

Geological Survey of South Africa (1985). Map of Tzaneen ( $\left.\mathrm{n}^{\circ} 2330\right), 1 / 250000$ edition.

Geological Survey of South Africa (1986). Pilgrim’s Rest (n² 2430), 1/250 000 edition.

Goad, B.E. and Cerny, P. 1981. Peraluminous pegmatitic granites and their pegmatite aureoles in the Winnipeg River District, southeastern Manitoba. The Canadian Mineralogist, 19, 177-194.

Goldstein, S.L., O'Nions, R.K. and Hamilton, P.J., 1984. A Sm-Nd isotopic study of atmospheric dusts and particulates from major river system. Earth and Planetary Science Letters, 70, 221-236.

Grace, R.L., Chamberlain, K.R., Frost, B.R. and Frost, C.D., 2006. Tectonic histories of the Paleo- to Mesoarchean Sacawee block and Neoarchean Oregon Trail structural belt of the south-central Wyoming Province. Canadian Journal of Earth Sciences, 43, 1445-1466.

Harris, N.B., Pearce, J.A., Tindle, A.G., 1986. Geochemical characteristics of collision-zone magmatism. Geological Society, London, Special Publications 19, 67-81.

Henderson, D.R., Long, L.E. and Barton, J.M., 2000. Isotopic ages and chemical and isotopic composition of the Archean Turfloop Batholith, Pietersburg granite-greenstone terrane, Kaapvaal Craton, South Africa. South African Journal of Geology, 103, 38-46.

Jackson, S.E., Pearson, N.J., Griffin, W.L. and Belousova, E.A., 2004. The application of laser ablationinductively coupled plasma-mass spectrometry to in situ $\mathrm{U}-\mathrm{Pb}$ zircon geochronology. Chemical Geology, 211, 47-69. 
Jaeckel, P. Kröner, A., Kamo, S.L., Brandl, G. and Wendt, J.I., 1997. Late Archean to early Proterozoic granitoid magmatism and high-grade metamorphism in the central Limpopo belt, South Africa. Journal of the Geological Society, 154, 25-44.

Jaguin, J., Boulvais, P., Poujol, M., Boiron, M.-C. and Cathelineau, M., 2010. Stable Isotope Composition of Quartz-Calcite Veins in the Witwatersrand Basin, South Africa: Implication for Basin-Scale Fluid Circulation. South African Journal of Geology, 113, 169-182.

Jaguin, J., Gapais, D., Poujol, M., Boulvais, P. and Moyen, J.-F., 2012a. The Murchison Greenstone Belt (South Africa): a General Tectonic Framework. South African Journal of Geology, 115, 65-76.

Jaguin, J., Poujol, M., Boulvais, P., Robb, L.J. and Paquette, J.-L., 2012b. Metallogeny of precious and base metal mineralization in the Murchison Greenstone Belt, South Africa: Indications from $\mathrm{U}-\mathrm{Pb}$ and $\mathrm{Pb}-\mathrm{Pb}$ geochronology. Mineralium Deposita, 47, 739-747.

Jaguin J., Boulvais, P., Poujol, M., Bosse, V., Paquette, J.-L. and Vilbert, D., 2013. Albitization in the Antimony Line, Murchison Greenstone Belt (Kaapvaal Craton): a geochemical and geochronological investigation. Lithos, 168-169, 124-143.

Jaguin, J., Boulvais, P. Boiron, M.C., Poujol, M., Gapais, D., Ruffet, G. and Briant, N., 2014. Stable isotopes $(\mathrm{C}, \mathrm{O})$ and fluid inclusion study of quartz-carbonate veins from the Antimony Line, Murchison Greenstone Belt. American Journal of Science, 314, 1140-1170.

Jahn, B.M. and Condie, K.C., 1995. Evolution of the Kaapvaal Craton as viewed from geochemical and Sm-Nd analyses of intracratonic pelites. Geochimica et Cosmochimica Acta, 59, 2239-2258.

Kreissig K., Nägler T.F., Kramers J.D., van Reenen D.D. and Smit C.A., 2000, An isotopic geochemical study of the northern Kaapvaal Craton and the Southern Marginal Zone of the Limpopo Belt: are they juxtaposed terranes? Lithos, 50, 1-25.

Kröner, A., Jaeckel, P., Brandl, G., Nemchin, A.A. and Pidgeon, R.T. 1999. Single zircon ages for granitoid gneisses in the Central Zone of the Limpopo Belt, Southern Africa and geodynamic significance. Precambrian Research, 93, 299-337

Kröner, A., Hoffmann, J.E., Wong, J.M., Geng, H.-Y., Schneider, K.P., Xie, H., Yang, J.-H. and Nhleko, N., 2019. Archaean crystalline rocks of the Eastern Kaapvaal Craton. The Archaean Geology of the Kaapvaal Craton, Southern Africa. Springer, 1-32. 
Kulikov, V.S., Kulikova, V.V., Safronova, G.P., Ovchinnkova, L.V., Zudin, A.I., Kazennova, A.D. and Kopylov, V.P. 1986. Archean muscovite rare metal-pegmatite belt at the southeast margin of the Baltic Shield. Transactions (Doklady) of the U.S.S.R. Academy of Sciences: Earth Science Sections, 291, 187-191. Laurent, O., Paquette, J.-L., Doucelance, R., Martin, M. and Moyen, J.-F., 2013. Crustal growth and evolution in the northern Kaapvaal Craton inferred by LA-ICP-MS dating of zircons from Meso- and NeoArchean granitoids. Precambrian Research, 30, 209-226.

Laurent, O., Martin, H., Moyen, J.-F. and Doucelance, R., 2014. The Diversity and Evolution of Late-Archean Granitoids: Evidence for the Onset of "Modern-Style" Plate Tectonics between 3.0 and 2.5 Ga. Lithos, 205, 208-235.

Laurent, O., Zeh, A., 2015. A linear Hf isotope-age array despite different granitoid sources and complex Archean geodynamics: Example from the Pietersburg block (South Africa). Earth and Planetary Science Letters 430, 326-338.

Laurent, O., Zeh, A., Brandl, G., Vézinet, A., Wilson, A., 2019. Granitoids and Greenstone Belts of the Pietersburg Block-Witnesses of an Archaean Accretionary Orogen Along the Northern Edge of the Kaapvaal Craton, in: A., K., A., H. (Eds.), The Archaean Geology of the Kaapvaal Craton, Southern Africa. Springer.

Larbi, Y., Stevenson, R., Breaks, F., Machado, N. and Gariépy, C. 1999. Age and isotopic composition of late Archean leucogranites: implications for continental collision in the western Superior Province. Canadian Journal of Earth Sciences, 36, 495-510.

Ludwig, K.R., 1998. On the treatment of concordant uranium-lead ages. Geochimica et Cosmochimica Acta 62:665-676.

Machado, N., Gariepy, C., Philippe, S. and David, J. 1990. Geochronologie U-Pb du territoire québecois : fosses de l'Ungava et du Labrador, province de Grenville et sous-provinces de Pontiac et de l'Abitibi. Rapport interimaire, Ministère de l'Energie et des Ressources du Québec, 50pp.

Maphalala, R.M. and Kröner, A., 1993. $\mathrm{Pb}-\mathrm{Pb}$ single zircon ages for the younger Archean granitoids of Swaziland, southern Africa. 16th International Colloquium on African Geology, Mbabane, Swaziland, 201206. 
Marschall, H.R., Hawkesworth, C.J., Storey, C.D., Dhuime, B., Leat, P.T., Meyer, H-P and Tamm-Buckle, S., 2010. The Annandagstoppane Granite, East Antarctica: Evidence for Archaean Intracrustal Recycling in the Kaapvaal-Grunehogna Craton from Zircon O and Hf Isotopes. Journal of Petrology 5, 2277-2301.

Marsh, J.S., 2006. The Dominion group The Geology of South Africa. Council for Geoscience, Pretoria, 149154.

Marxer, F., Ulmer, P., 2019. Crystallisation and zircon saturation of calc-alkaline tonalite from the Adamello Batholith at upper crustal conditions: an experimental study. Contributions to Mineralogy and Petrology 174, 84.

McCarthy, T.S. 2006. The Witwatersrand supergroup. The Geology of South Africa. Council for Geoscience, Pretoria, 155-186.

McCourt, S., Hilliard, P. and Armstrong, R.A., 2000. SHRIMP U-Pb zircon geochronology of granitoids from the western margin of the Kaapvaal Craton: implications for crustal evolution in the NeoArchean. In: A.F.M. Kisters and R.J. Thomas (Editors). Proceedings of the 27th Geocongress. Geological Society of South Africa, Stellenbosch. Journal of African Earth Sciences, 31, 48.

McLennan, S.M., Taylor, S. and Eriksson, K., 1983. Geochemistry of Archean shales from the Pilbara Supergroup, western Australia. Geochimica et Cosmochimica Acta, 47, 1211-1222.

Meyer, F.M., Reimold, W.U. and Walraven, F., 1993. The evolution of the Archaean granite crust in the southeastern Kaapvaal Craton, South Africa. In: Terra Abstracts, 1:319, EUG VII, Strasbourg, France.

Meyer, F.M., Robb, L.J., Reimold, W.U. and de Bruin, H., 1994. Contrasting low and high Ca granites in the Archean Barberton Mountain Land, southern Africa. Lithos, 32, 63-76.

Miller, C.F., Stoddard, E.F., Bradfish, L.J. and Dollase, W.A., 1981. Composition of plutonic muscovite: genetic implications. Canadian Mineralogist, 19, 25-34.

Miller, C.F., McDowell, S.M., Mapes, R.W., 2003. Hot and cold granites? Implications of zircon saturation temperatures and preservation of inheritance. Geology 31, 529-532.

Moyen, J.-F., 2019. Archean granitoids: classification, petrology, geochemistry and origin. Geological Society, London, Special Publications 489:SP489-2018-2034.

Moyen, J.F. (Eds.), Archean Granitoids of India: Windows into Early Earth Tectonics. Geological Society of London. 
Moyen, J.-F., Zeh, A., Cuney, M., Dziggel, A., Carrouée, S., submitted. The multiple ways of recycling Archaean crust: a case study from the ca. $3.1 \mathrm{Ga}$ granitoids from the Barberton Greenstone Belt, South Africa. Precambrian Research.

Paquette, J.-L., Piro, J.L., Devidal, J.-L., Bosse, V., Didier, A., Sanac, S., Abdelnour, Y. 2014. Sensitivity enhancement in LA-ICP-MS by N2 addition to carrier gas: Application to radiometric dating of U-Th-bearing minerals. Agilent ICP-MS Journal, 58, 1-5.

O'Neil, J.R., Shaw, S.E., Flood, R.H., 1977. Oxygen and hydrogen isotope compositions as indicators of granite genesis in the New England Batholith, Australia. Contributions to Mineralogy and Petrology, 62, 313-328.

Poujol, M., 2001. U-Pb isotopic evidence for episodic granitoid emplacement in the Murchison greenstone belt, South Africa. Journal of African Earth Sciences, 33, 155-163.

Poujol, M. and Robb, L.J., 1999. New U-Pb zircon ages on gneisses and pegmatites from south of the Murchison Greenstone belt, South Africa. South African Journal of Geology, 102, 93-97.

Poujol M., Robb L.J., Respaut J.-P. and Anhaeusser C.R., 1996. 3.07-2.97 Ga greenstone belt formation in the northeastern Kaapvaal Craton: implications for the origin of the Witwatersrand Basin. Economic Geology, $91,1455-1461$.

Poujol, M., Robb, L.J. and Anhaeusser, C.R., Gericke, B., 2003. A Review of the Geochronological Constraints on the Evolution of the Kaapvaal Craton, South Africa. Precambrian research 127, 181-213.

Poujol, M., Pitra, P., Van Den Driessche, J., Tartèse, R., Ruffet, G., Paquette, J.-L. and Poilvet, J.-C., 2017. Twostage partial melting during the Variscan extensional tectonics (Montagne Noire, France). International Journal of Earth Sciences, 106, 477-500.

Robb, L.J., Brandl, G., Anhaeusser, C.R. and Poujol, M., 2006. Archean granitoid intrusions of the Kaapvaal Craton. In: M.R. Johnson, C.R. Anhaeusser and R.J. Thomas (Editors), 2006. The Geology of South Africa. The Geological Society of South Africa, Council for Geoscience, Pretoria, 57-94.

Sanchez-Garrido, C.J.M.G., Stevens, G., Armstrong, R.A., Moyen, J.-F., Martin, H. and Doucelance, R., 2011. Diversity in Earth's early felsic crust: Paleoarchean peraluminous granites of the Barberton Greenstone Belt. Geology, 39, 963-966.

Sarvothaman, H. and Leelanandam, C., 1987. Petrography and major oxide chemistry of the Archean granitic rocks of the Medak area, Andhra Pradesh. Journal of the Geological Society of India, 30, 194-209. 
Stokes, T.R., 1991. The Xinguara Granite, evidence of monzogranitic magmatism in the Archean of eastern Amazonia, Brazil. PhD thesis, Dalhousie University, Halifax, Canada.

Tartèse, R. and Boulvais, P., 2010. Differentiation of peraluminous leucogranites ,"en route" to the surface. Lithos 114, 353-368.

Taylor S.R. and Hugh P., 1978. Oxygen and hydrogen isotope studies of plutonic granitic rocks. Earth and Planetary Science Letters, 38, 177-210.

Taylor, S.R., McLennan, S.M., 1985. The continental crust: its composition and evolution. Blackwell, Oxford. Taylor, J., Stevens, G., Armstrong, R. and Kisters, A.F.M., 2010. Granulite facies anatexis in the Ancient Gneiss Complex, Swaziland, at 2.73 Ga: Mid-crustal metamorphic evidence for mantle heating of the Kaapvaal craton during Ventersdorp magmatism. Precambrian Research, 177, 88-102.

Toulkeridis, T., Clauer, N., Kroner, A., Reimer, T. and Todt, W., 1999. Characterization, provenance, and tectonic setting of Fig Tree greywackes from the archaean Barberton Greenstone Belt, South Africa. Sedimentary Geology, 124, 113-129.

Van Achterbergh, E., Ryan, C.G., Jackson, S.E. and Griffin, W.L., 2001. Data reduction software for LA-ICPMS: appendix. In: P.J. Sylvester (editor), 2001. Laser Ablation-ICP-Mass Spectrometry in the Earth Sciences: Principles and Applications. Mineralogical Association of Canada; Short Courses Series, Ottawa, Ontario, Canada, 29, 239-243.

Van Reenen, D.D., Smit, C.A., Perchuk, A.L., Huizenga, J.M., Safonov, O.G., Gerya, T.V., 2019. The NeoArchaean Limpopo orogeny: Exhumation and regional-scale gravitational crustal overturn driven by a granulite diapir, The Archaean Geology of the Kaapvaal Craton, Southern Africa. Springer, pp. 185-224.

Vearncombe, J.R., 1988. Structure and Metamorphism of The Archean Murchison Belt, Kaapvaal Craton, SouthAfrica. Tectonics, 7, 761-774.

Vearncombe, J.R., Barton, J.M., Cheshire, P.E., de Beer, J.H., Stettler, E.H. and Brandl, G., 1992. Geology, geophysics and mineralization of the Murchison Schist Belt, Rooiwater Complex and surrounding granitoids. Memoir of the Geological survey of South Africa ${ }^{\circ} 81$.

Vennemann, T.W., Kesler, S.E., Frederickson, G.C., Minter, W.E. and Heine, R.R., 1996. Oxygen Isotope Sedimentology of Gold- and Uranium-Bearing Witwatersrand and Huronian Supergroup Quartz-Pebble Conglomerates. Economic Geology, 91, 322-342. 
Vennemann, T. W., Kesler, S. E. and O’Neil, J. R., 1992. Stable isotope compositions of quartz pebbles and their fluid inclusions as tracers of sediment provenance: Implications for gold- and uranium-bearing quartz pebble conglomerates. Geology, 20, 837-840.

Vermeesch, P., 2018. IsoplotR: A free and open toolbox for geochronology. Geoscience Frontiers 9:1479-1493.

Vézinet, A., Moyen, J.F., Stevens, G., Nicoli, G., Couzinié, S., 2018. A record of 0.5 Ga of evolution of the continental crust along the northern edge of the Kaapvaal Craton, South Africa: consequences for the understanding of Archaean geodynamic processes. Precambrian Research 305, 310-326.

Villaros, A., Moyen, J.-F., Abelanet, J., 2011. Textural development of granites: Super- and sub-solidus evolution of the Mashishimale Pluton (South Africa). VII Hutton Symposium: Granites and associated Rocks. Avila, Spain.

Villaros, A., Buick, I. and Stevens, G., 2012. Isotopic variations in S-type granites: an inheritance from a heterogeneous source? Contributions to Mineralogy and Petrology, 163, 243-257.

Villaros, A., Laurent, O., Couzinié, S., Moyen, J.F., Mintrone, M., 2018. Plutons and domes: the consequences of anatectic magma extraction - Example from the South-Eastern French Massif Central. International Journal of Earth Sciences.

Villaseca, C., Barbero, L., Herreros, V., 1998. A re-examination of the typology of peraluminous granite types in intracontinental orogenic belts. Transactions of the Royal Society of Edinburgh: Earth Sciences 89, 113119.

Vinnik L.P., Green R.W.E and Nicolaysen, L.O., 1995. Recent deformations of the deep continental root beneath southern Africa. Nature, 375, 50-52.

Watson, E.B., Harrison, T.M., 1983. Zircon saturation revisited: temperature and composition effects in a variety of crustal magmas types. Earth and Planetary Science Letters 64, 295-304.

White, A.J.R., Chappell, B.W., 1983. Granitoid types and their distribution in the Lachlan fold belt, southeastern Australia, in: Roddick, J.A. (Ed.), Circum-Pacific plutonic terranes. Geological Society of America, pp. 2134.

White, A.J.R., Clemens, J.D., Holloway, J.R., Silver, L.T., Chappell, B.W., Wall, V.J., 1986. S-Type Granites and Their Probable Absence in Southwestern North-America. Geology 14, 115-118. 
Wiedenbeck, M., Alle, P., Corfu, F., Griffin, W.L., Meier, M., Oberli, F., von Quadt, A., Roddick, J.C. and Spiegel, W., 1995. Three natural zircon standards for U-Th-Pb, Lu-Hf, trace element and REE analyses. Geostandards Newsletter, 19, 1-23.

Wilde, S.A., Valley, J.W., Peck, W. and Graham, C.M., 2001. Evidence from detrital zircons for the existence of continental crust and ocean on the Earth 4.4 Gyr ago. Nature, 409, 175-178.

Zeh, A., Gerdes, A. and Barton, J.M., 2009. Archean Accretion and Crustal Evolution of the Kalahari Cratonthe Zircon Age and Hf Isotope Record of Granitic Rocks from Barberton/Swaziland to the Francistown Arc. Journal of Petrology, 50, 933-966.

Zeh, A. and Gerdes, A., 2012. U-Pb and Hf isotope record of detrital zircons from gold-bearing sediments of the Pietersburg Greenstone Belt (South Africa)-Is there a common provenance with the Witwatersrand Basin? Precambrian Research, 204, 46-56.

Zeh, A., Gerdes, A. and Heubeck, C., 2013. U-Pb and Hf isotope data of detrital zircons from the Barberton Greenstone Belt: constraints on provenance and Archaean crustal evolution. Journal of the Geological Society, 170, 215-223.

Zeh, A., Jaguin, J., Poujol, M., Boulvais, P., Hallot, E., Block, S. and Paquette, J.-L., 2013. Juvenile crust formation in the northeastern Kaapvaal Craton at $2.97 \mathrm{Ga}$ - Implications for Archean crust-mantle evolution, terrane accretion, and the Witwatersrand gold source. Precambrian Research, 233, 20-43. 


\section{FIGURES AND TABLES CAPTIONS}

Figure 1: (a) Map of the northeastern Kaapvaal Craton after Robb et al., 2006. TML: ThabazimbiMurchison Lineament. HRSZ: Hout River Shear Zone (b) Map of the Murchison Granite Greenstone Belt Terrain. Only the La France Formation is identified within the volcano-sedimentary sequence. On Lekkersmaak and Willie plutons, the reported number are sampling sites corresponding to samples MUR 09xx. Belt limits are from Vearncombe et al. (1992); basement and intrusives are from 1:250 000 map of Tzaneen (Geological Survey of South Africa 1985) and Pilgrim's Rest (1986); mapping of the Willie pluton and western part of the Lekkersmaak plutons are from Ian Kramers (pers. comm).

Figure 2: Pictures of the Lekkersmaak and Willie rocks. Hand samples of: (a) medium-grained, equigranular biotite-muscovite quartzo-feldspatic rock with a rare example of garnet (MUR 09-67); (b) biotiterich, muscovite-poor porphyritic facies with cm-large feldspar (MUR 09-66); (c) outer, foliated sample (MUR 09-72, bar scale $2 \mathrm{~cm}$ ). Thin section pictures of: (d) intergrowth of biotite and muscovite (sample MUR 0980, bar scale $600 \mu \mathrm{m}$ ); (e) large muscovite grains (Ms), in place sheared, along with a fine grained matrix of biotite (Bt) + epidote (Ep) + titanite (Tnt) (MUR 09-108, Willie granite, bar scale $400 \mu \mathrm{m})$.

Figure 3: Mineral composition. (a) End-member ternary diagram of feldspar. (b) Chemical ternary diagram of muscovite. Dashed line separates the field of primary plutonic muscovite composition (top) from the field of secondary muscovite (after Miller et al., 1981). "Secondary", "maybe secondary" and "primary" terminology refer to textural criteria such as size distribution, dissolution figures, association with secondary minerals (epidote, titanite), or association with shear zones.

Figure 4: Harker diagrams of the Lekkersmaak samples (black squares), plus S-types plutons worldwide (grey, dark grey for Archean ones).

Figure 5: B-A diagram of the Lekkersmaak samples. Red squares (samples MUR 09-60, 09-61, 0966, 09-109, 18c, 09-80, 09-72, 8a), red circle (MUR 09-108), green squares (MUR 09-63 and 09-67). f-P: Highly Felsic Peraluminous granitoids; h-P: Highly Peraluminous granitoids; m-P: Moderately Peraluminous granitoids; I-P: Low Peraluminous granitoids.

Figure 6: REE patterns of the studied samples normalized to the average Archean Shale values of (Taylor and McLennan, 1985). Red squares (Lekkersmaak samples MUR 09-60, 09-61, 09-66, 09-109, 18c, 09-80, 09-72, 8a), green squares (Lekkersmaak samples MUR 09-63 and 09-67), red circle (Willie Granite MUR 09-108), Black line and black cross (Average Regional TTG). 
Figure 7: Cathodoluminescence imaging of some of the dated grains from the Lekkersmaak and Willie plutons. Red circles correspond to the analytical spots (26 microns) while the numbers are the ${ }^{207} \mathrm{~Pb} /{ }^{206} \mathrm{~Pb}$ ages (errors are at 1 sigma).

Figure 8: Concordia diagrams of various samples from the Lekkersmaak pluton (a and b) and Willie pluton (c).

Figure 9: $\varepsilon N d$ versus time. Grey domain is that of the samples from the Lekkersmaak pluton. DM: Depleted Mantle curve from Goldstein et al. (1984).

Figure 10: $\mathrm{Na} / \mathrm{K}$ mol ratio versus $\delta^{18} \mathrm{O}$ whole rock values.

Table 1: Mineral chemistry of feldspar and muscovite. Average electron microprobe analyses (wt.\%) and corresponding structural formulae (apfu: atom per formula unit.). m: number of grains, n: number of analyses.

Table 2: Whole rock chemistry. Major elements in wt\%, trace elements in ppm and $\delta 180$ in \%ovs SMOW. Errors and detection limits: see Carignan et al., 2001. bdl: below detection limit. ms: muscovite; gt: garnet; WR: whole rock; bdl: below detection limit; nd: not determined. La/YbN normalized to chondrite (Evansen et al., 1978)

Table 3: Zircon isotopic data. All errors are listed at $1 \sigma$. In bold are the data used to calculate concordia ages.

Table 4: Sm-Nd and Rb-Sr isotopic compositions. 1: parameters ${ }^{143} \mathrm{Nd} /{ }^{144} \mathrm{Nd}$ CHUR $=0.512638$; ${ }^{147} \mathrm{Sm} /{ }^{144} \mathrm{Nd}$ CHUR $=0.1967 ;{ }^{147} \mathrm{Sm}: \lambda=6.54 \times 10^{-12} \mathrm{yr}^{-1} .2$ : from Goldstein et al. 1984. 3: measured by ICPMS. 4: $\mathrm{ISr}=$ initial ${ }^{87} \mathrm{Sr} /{ }^{86} \mathrm{Sr} ; \lambda\left({ }^{87} \mathrm{Rb}\right)=1.42 \times 10^{-11} \mathrm{yr}^{-1} ; 5: \varepsilon_{\mathrm{Nd}}$ and $\mathrm{I}_{\mathrm{Sr}}$ calculated with $\mathrm{t}=2816 \mathrm{Ma}$

Supplementary Table 1: GPS coordinates of the studied samples

Supplementary Table 2: LA-ICP-MS Analytical Protocol for the zircon U-Th-Pb dating and Isotopic values for the 91500 zircon secondary standards analyzed during this study. 
Fig. 1A: $\square$ INTRUSIONS

Ma: Matala granite

Mo: Molestsi granite

Mas: Mashashane

Mk: Matok

D: Duivelskloof granite

T:Turfloop granite

$\mathrm{H}$ : Harmony granite

Fig. 1B:

L_ Msh: Mashishimale pluton

x granodiorite M: Maranda

B: Baderoukwe

으을 W: Willie porphyritic granite

+ + L: Lekkersmaak leucogranite

$\therefore$ porphyritic facies
Greenstone Belts

1: Giyani

2: Pietersburg

3: Rhenosterkoppies

4: Murchison - fig. 1b:

GNeISSIC BASEMENT

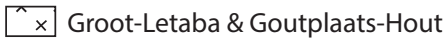

$\gg$ Makhutswi

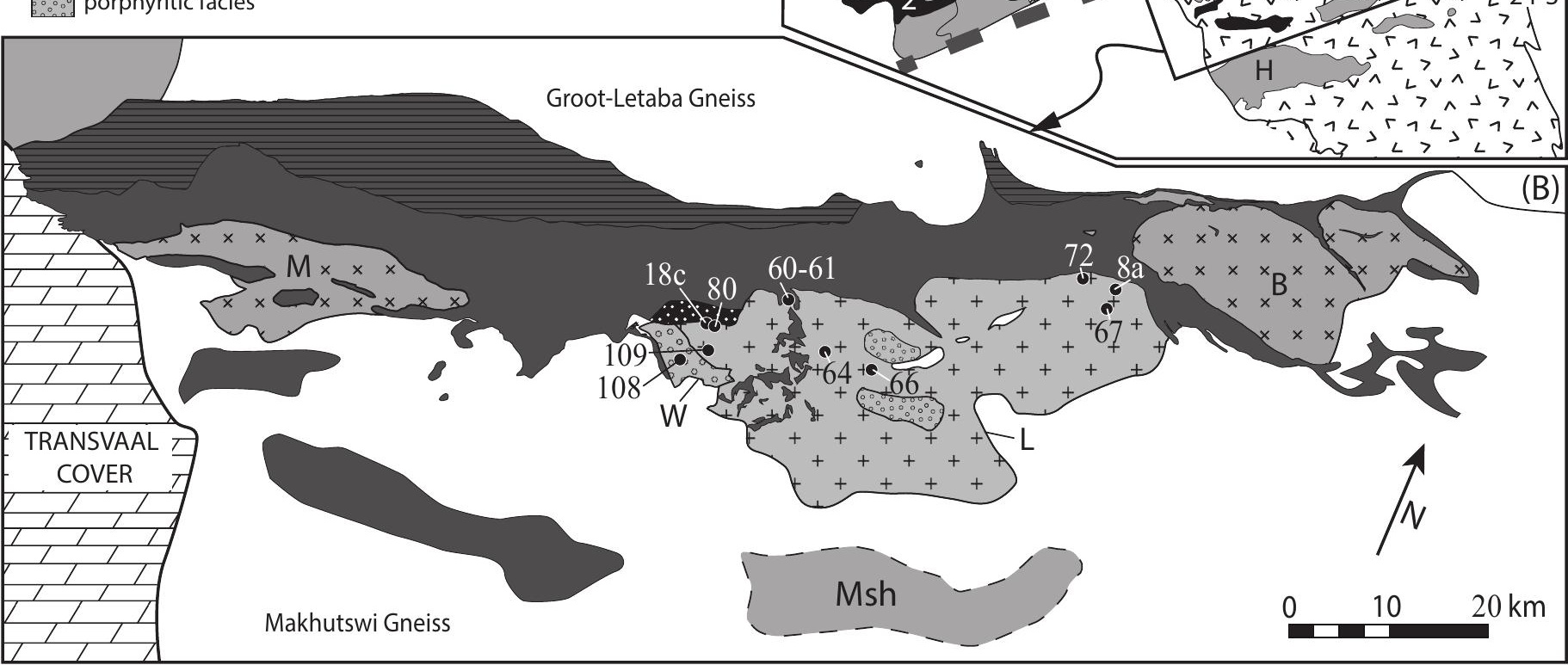

mafic-to felsic, volcanic and sedimentary unit

$\because \because$ La France Formation

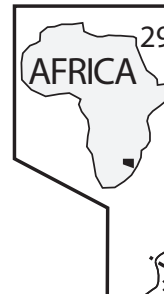

(A)

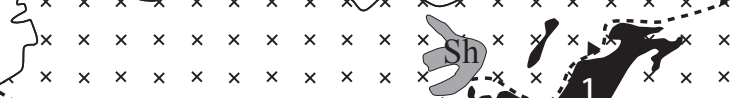

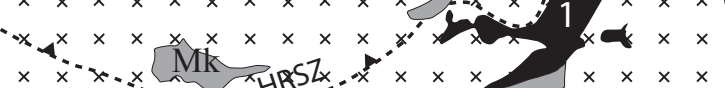




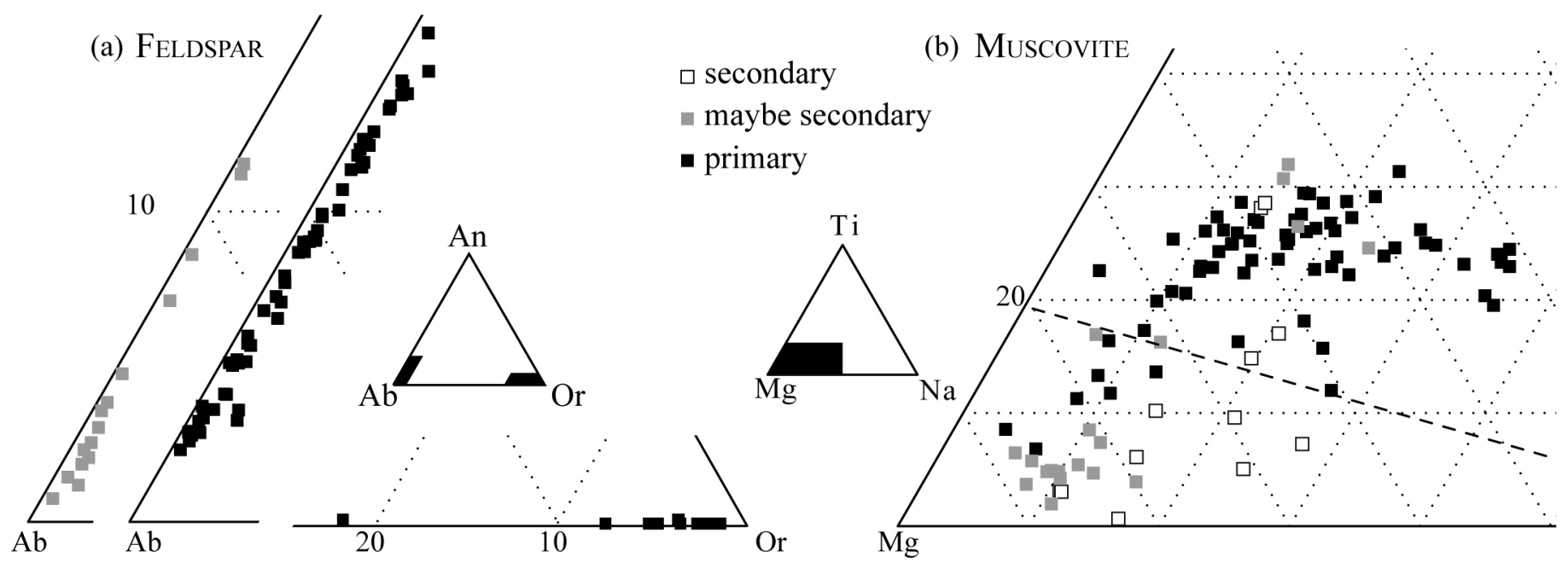



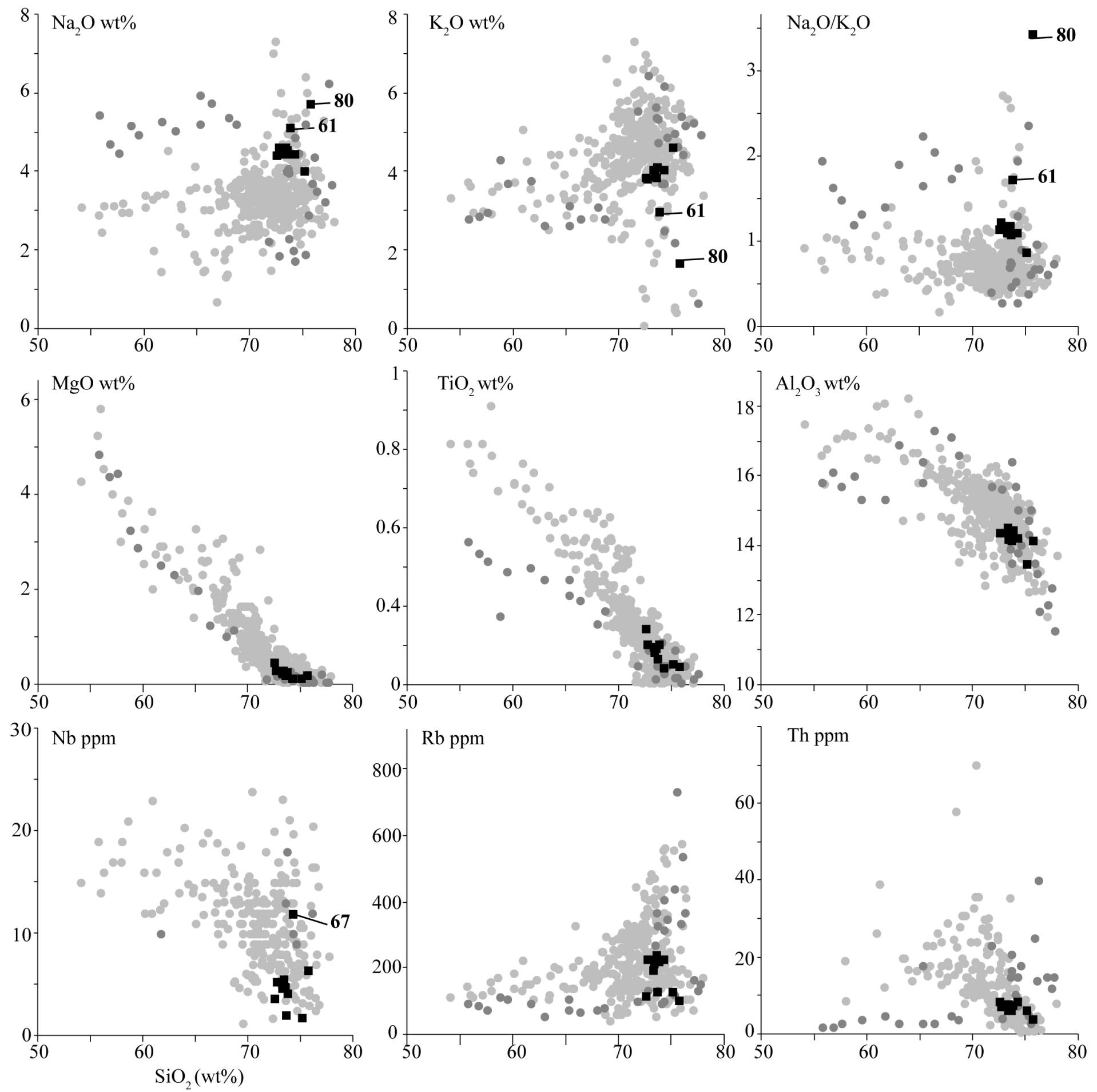


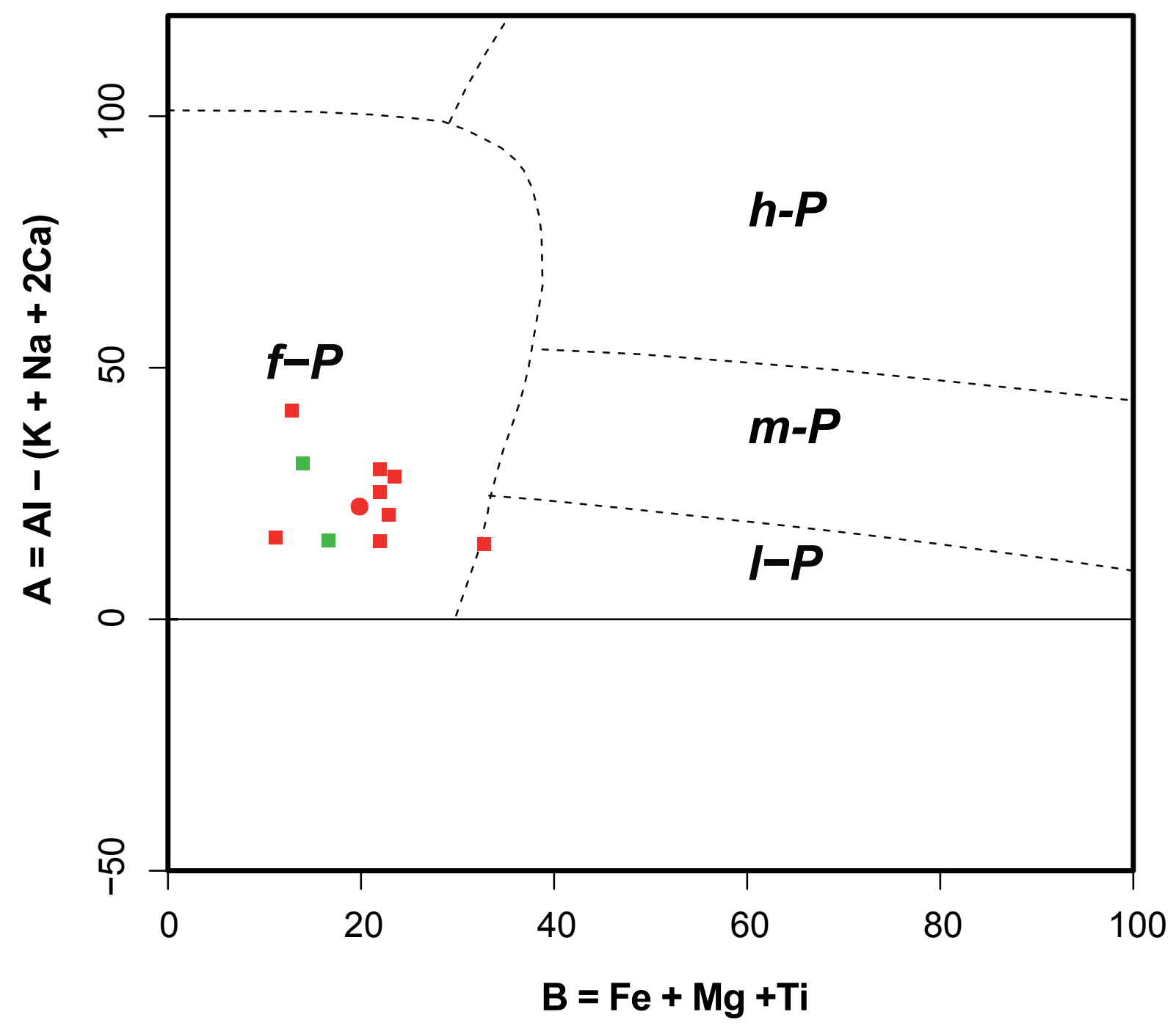




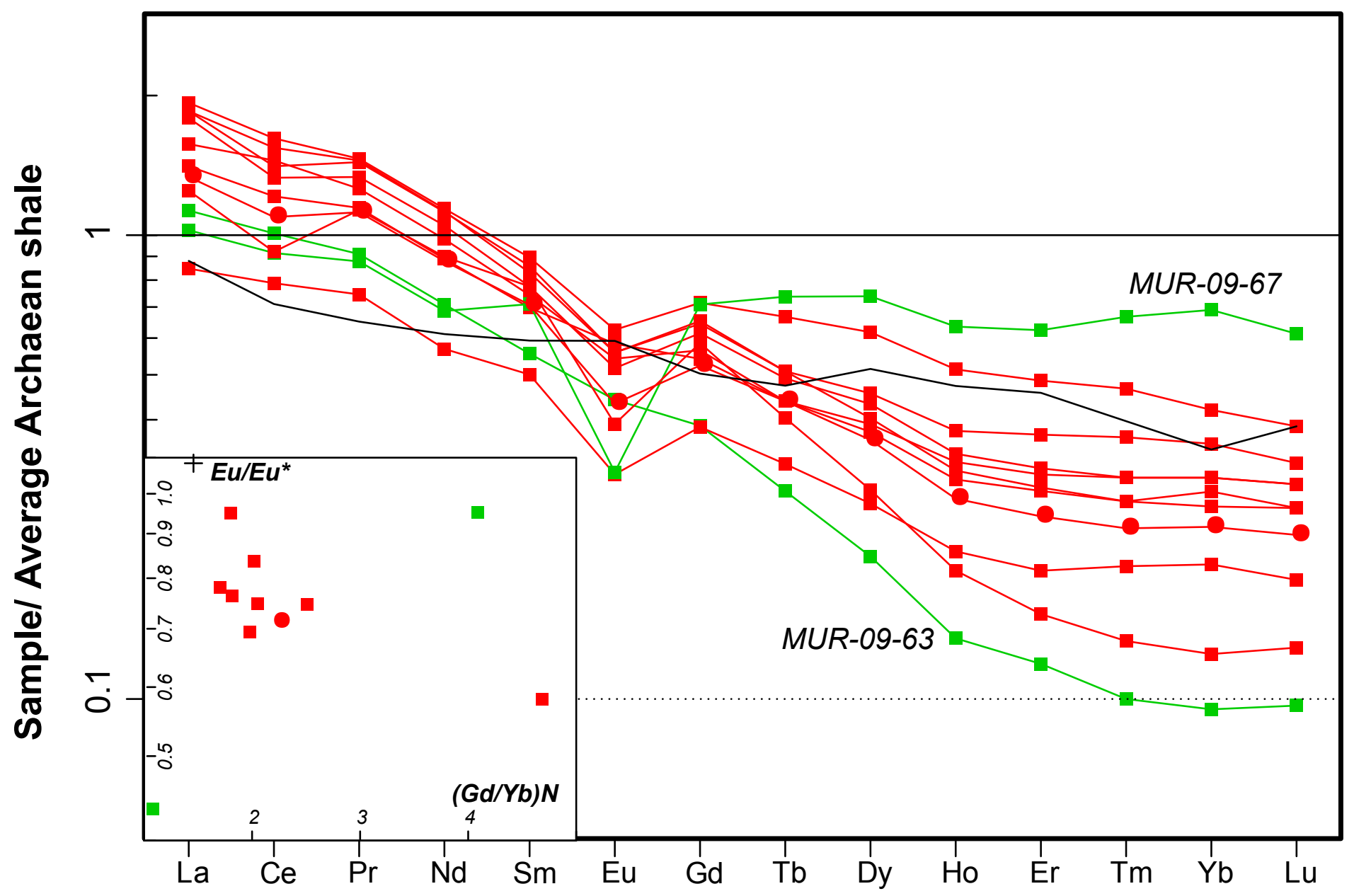




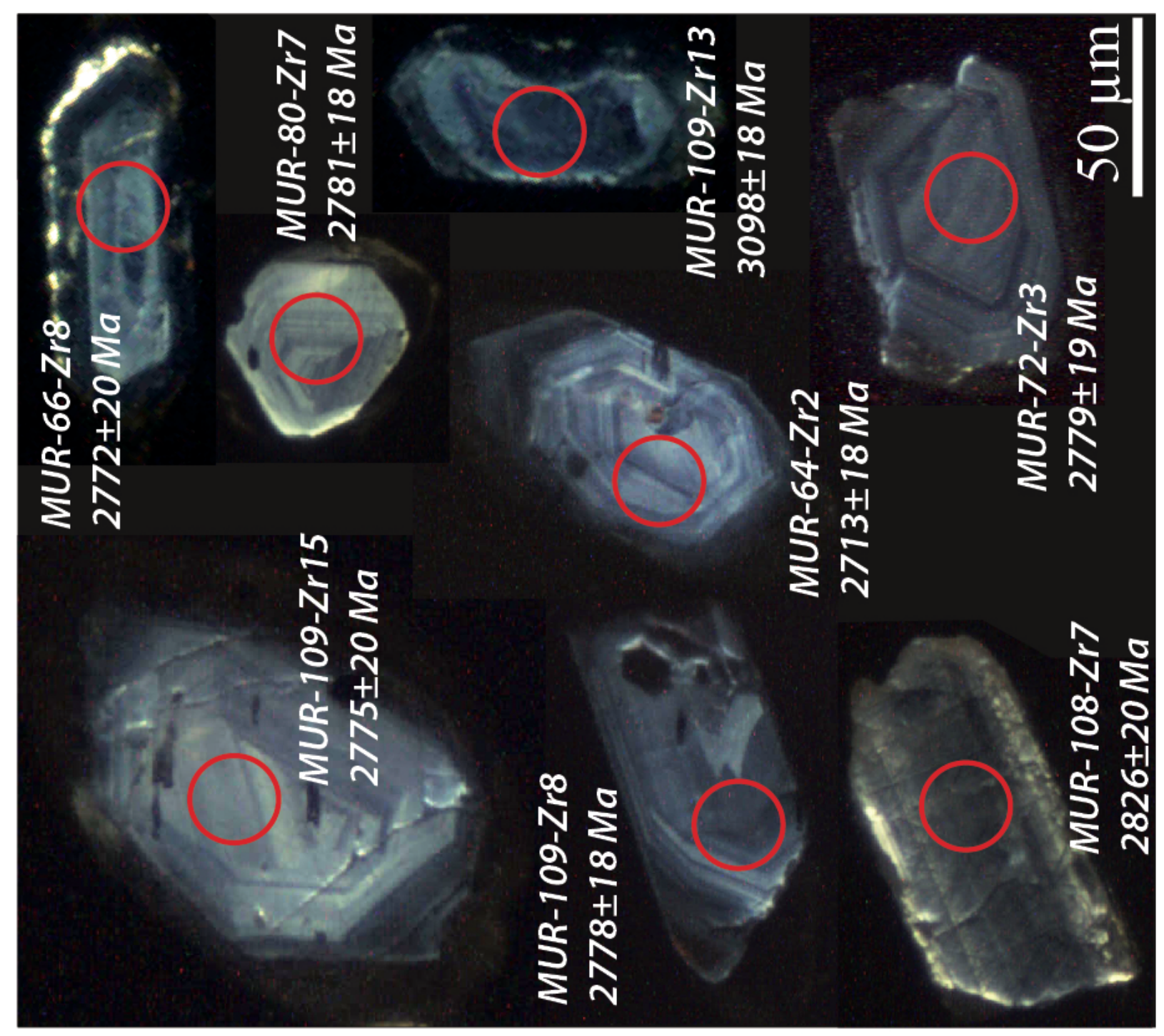



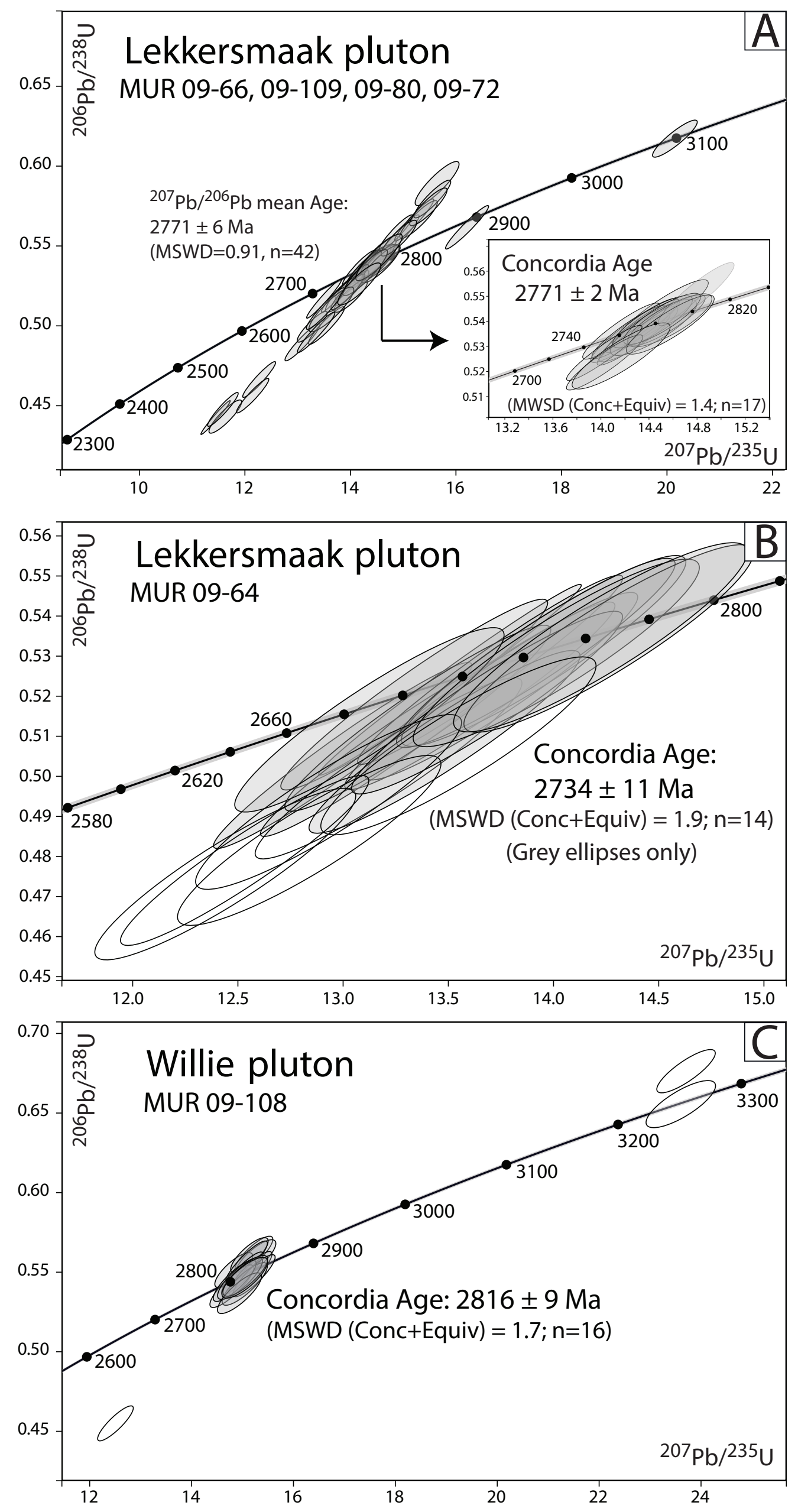


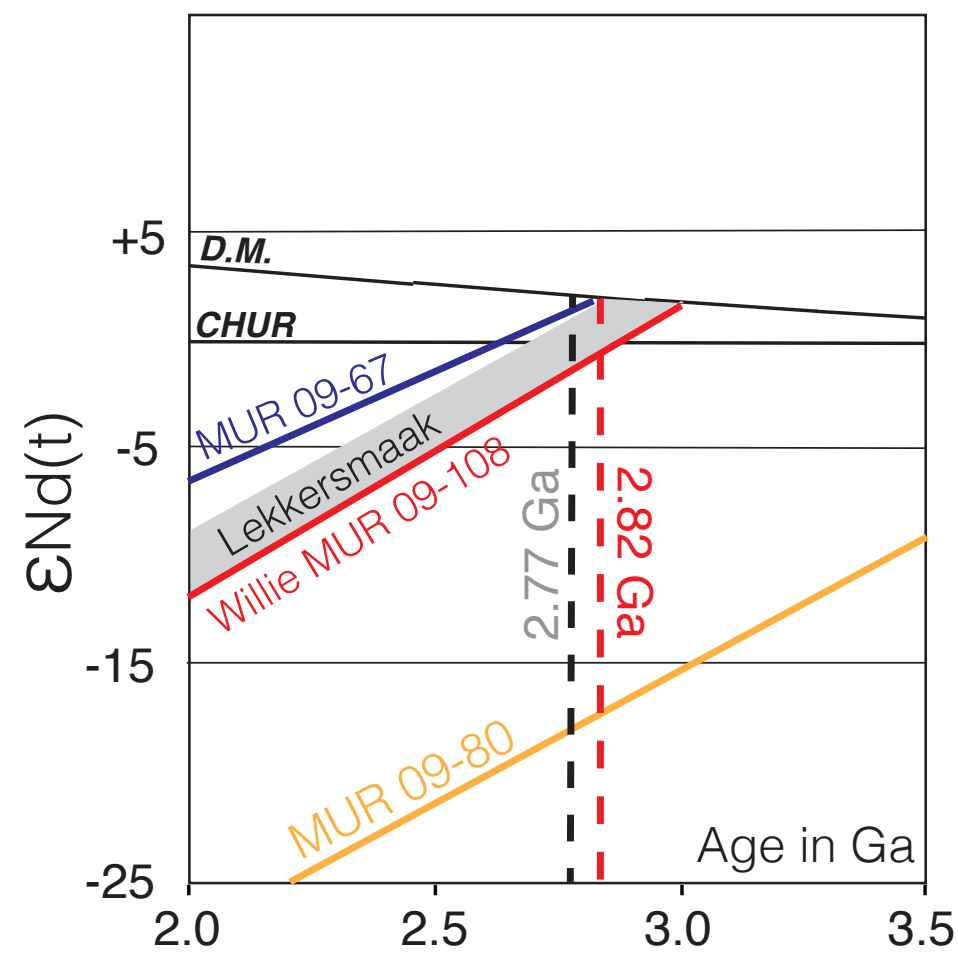


$\mathrm{Na} / \mathrm{K}_{\text {mol }}$

6[

5

MUR 09-80

3

4

2

0

8.0

$8.5 \quad 9.0$

9.5

$\delta^{18} \mathrm{O}(\%$ vs SMOW) 
TABLE 1 (Poujol et al.)

\begin{tabular}{l|c} 
LEKKERSMAAK GRANITE & WILLIE \\
GRANITE
\end{tabular}

MUR 09- $\quad$ MUR 09- $\quad$ MUR 09- $\quad$ MUR 09- $\quad$ MUR 09- $\quad$ MUR 09-

\begin{tabular}{rrccccc|c} 
& sample & $\mathbf{6 1}$ & $\mathbf{6 6}$ & $\mathbf{1 0 9}$ & $\mathbf{6 7}$ & $\mathbf{7 2}$ & $\mathbf{1 0 8}$ \\
\hline K-feldspar & & $m=1, n=2$ & $m=1, n=1$ & $m=5, n=6$ & $m=2, n=4$ & $n=1$ & \\
& $\mathbf{S i O}_{2}$ & 63.81 & 64.09 & 64.36 & 64.57 & 65.79 & \\
$\mathbf{A l}_{\mathbf{2}} \mathbf{O}_{\mathbf{3}}$ & 18.49 & 18.56 & 18.38 & 18.43 & 18.60 & \\
$\mathbf{C a O}$ & 0.41 & 0.25 & 0.59 & 0.22 & 2.47 & \\
$\mathbf{N a 2 O}$ & 16.33 & 17.00 & 16.20 & 16.85 & 13.69 & \\
$\mathbf{K 2 O}$ & 0.04 & 0.00 & 0.00 & 0.00 & 0.07 & \\
$\mathbf{S U M}$ & 99.08 & 99.89 & 99.53 & 100.06 & 100.62 & \\
& Structural formula based on 8 oxygen atoms & & \\
$\mathbf{S i}$ & 2.98 & 2.98 & 2.99 & 2.99 & 3.00 & \\
$\mathbf{A l}$ & 1.02 & 1.02 & 1.01 & 1.01 & 1.00 & \\
$\mathbf{C a}$ & 0.00 & 0.00 & 0.00 & 0.00 & 0.00 & \\
$\mathbf{N a}$ & 0.04 & 0.02 & 0.05 & 0.02 & 0.22 & \\
$\mathbf{K}$ & 0.97 & 1.01 & 0.96 & 1.00 & 0.79 & \\
$\mathbf{S U M}$ & 5.01 & 5.03 & 5.01 & 5.01 & 5.01
\end{tabular}

End-member feldspar, mole \%

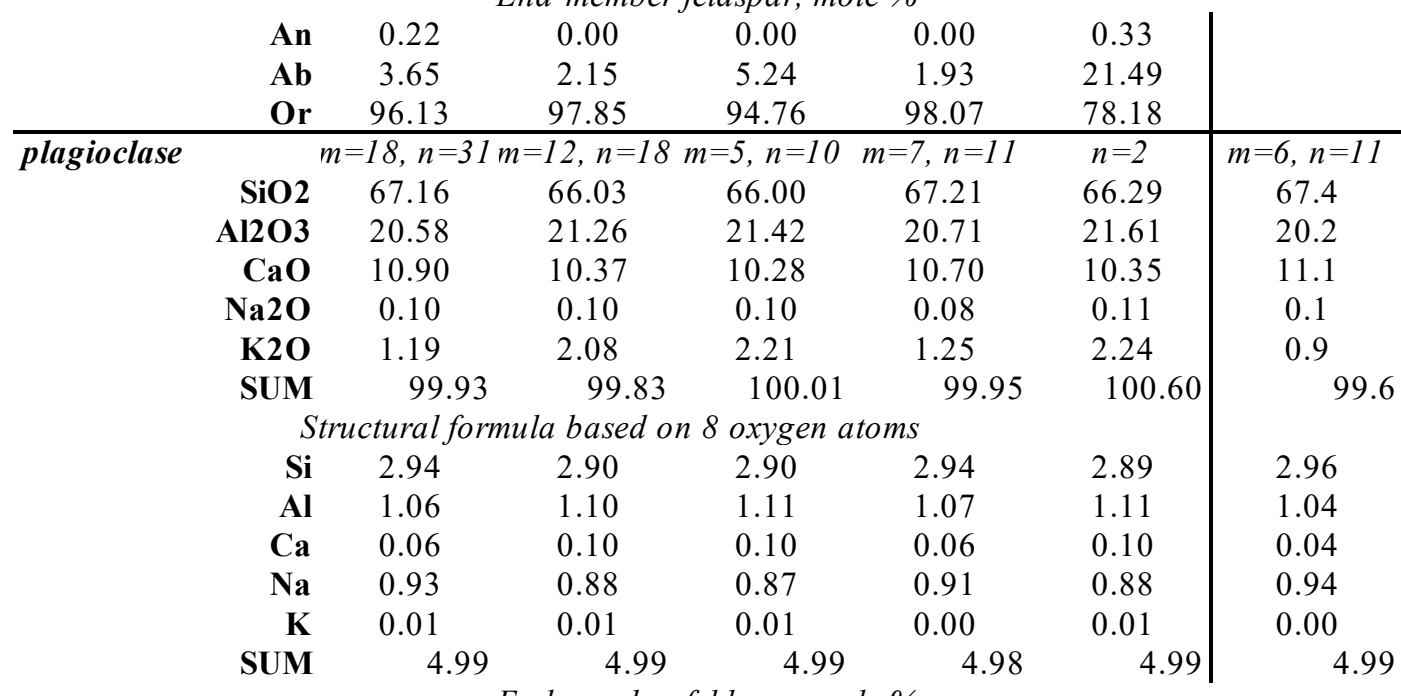

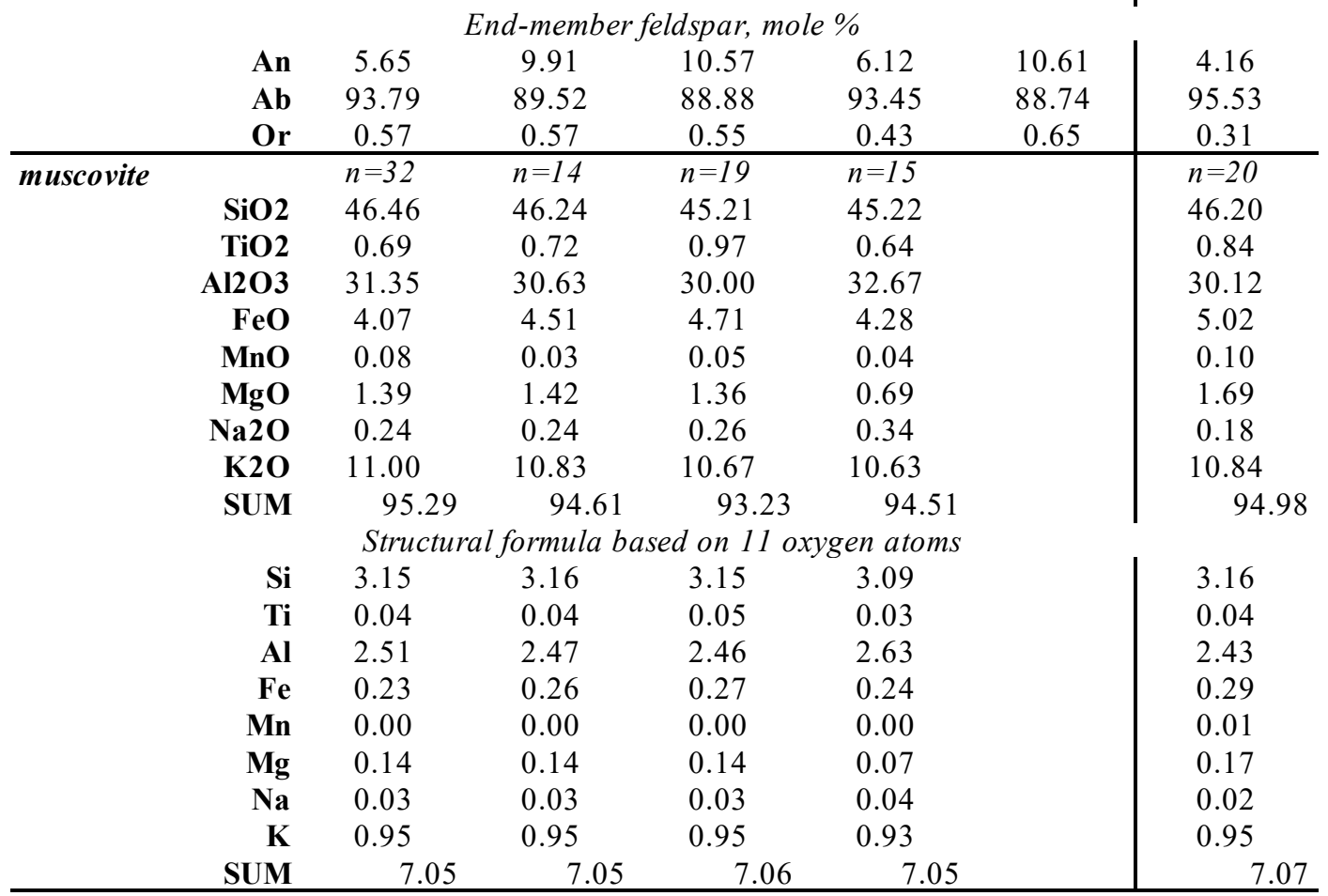


MUR 09- MUR 09- MUR 09- MUR 09- MUR 09- MUR MUR 09- MUR 09- MUR 09-

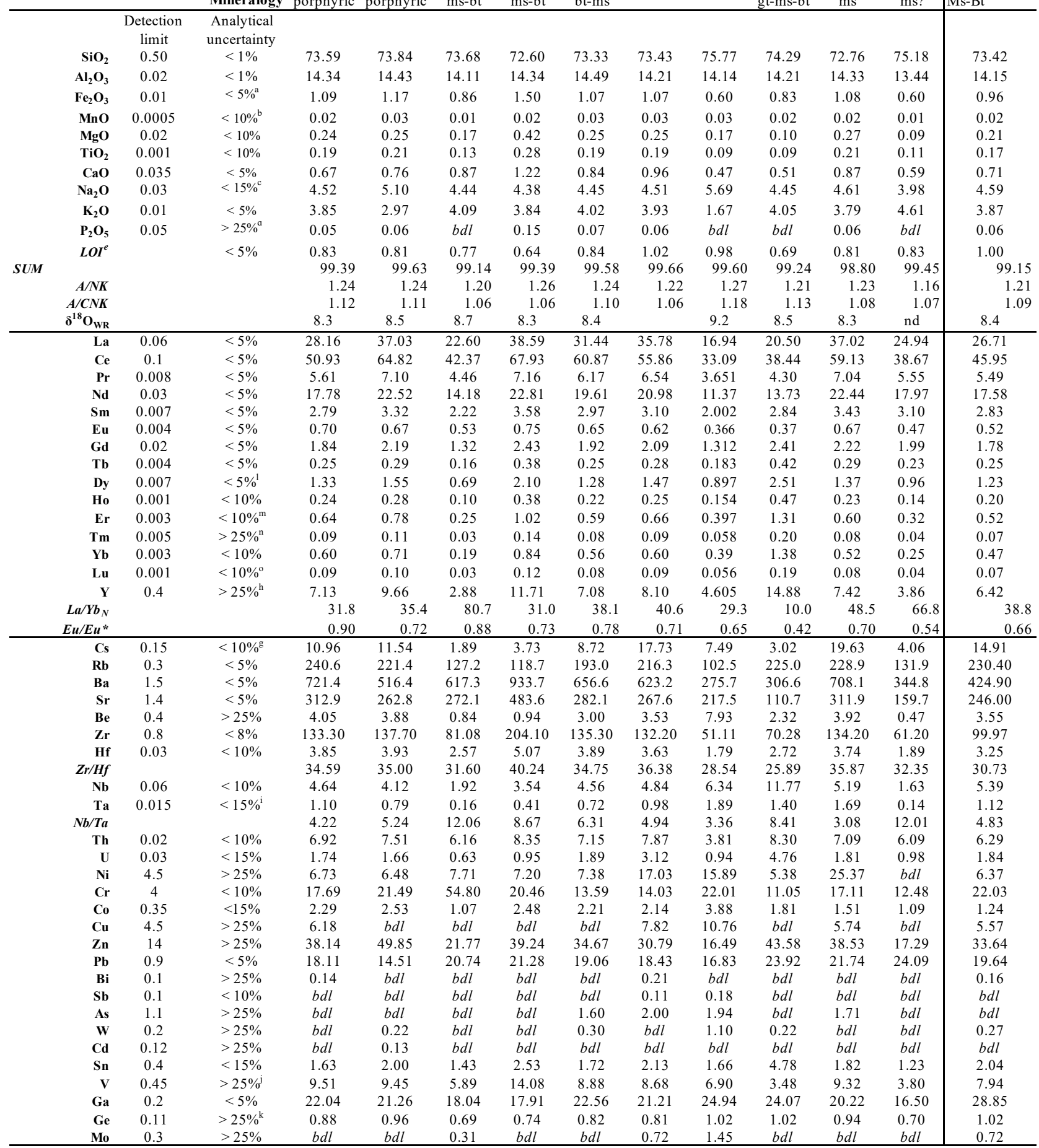




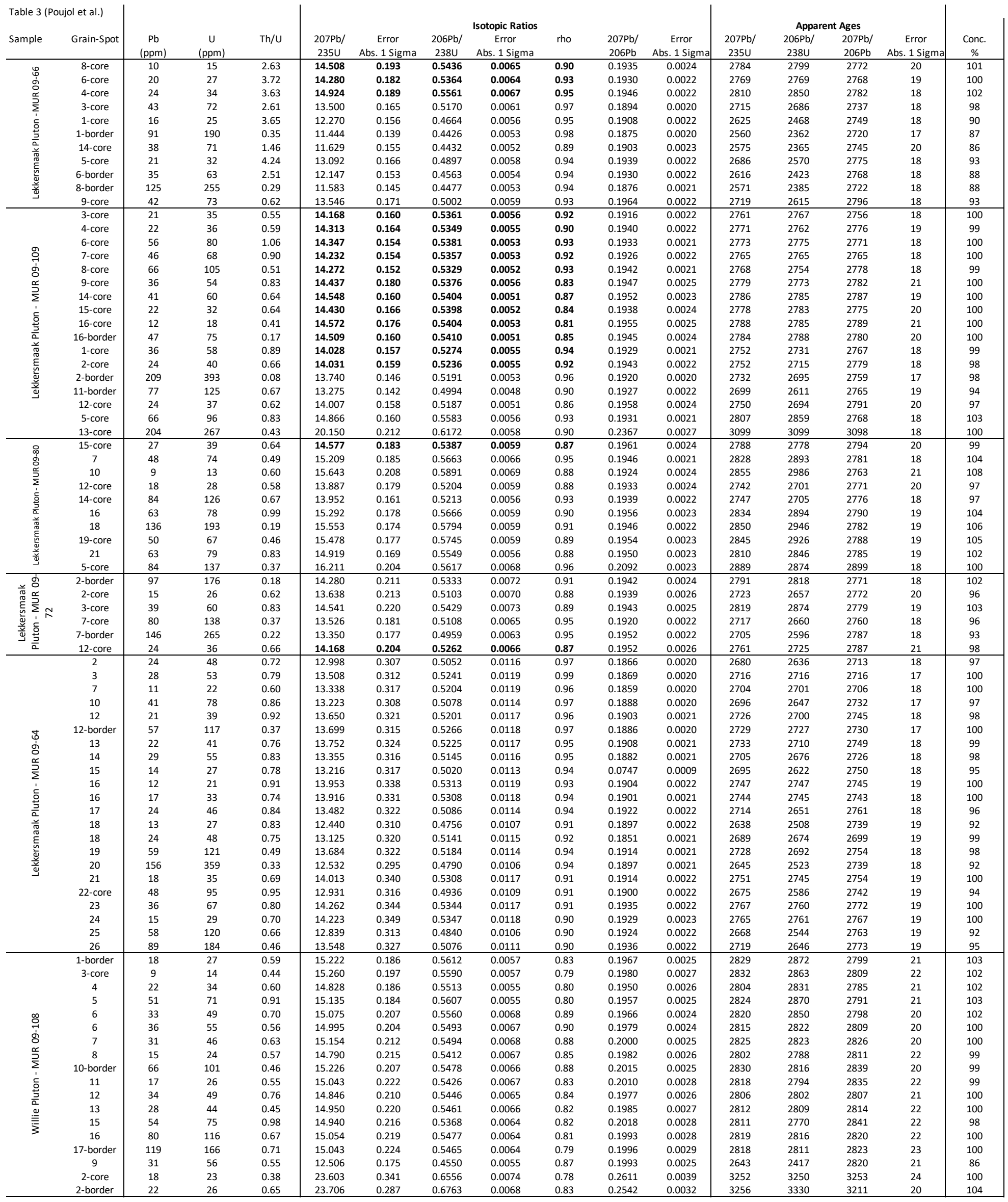


Table 4 (Poujol et al.)

\begin{tabular}{|c|c|c|c|c|c|c|c|c|c|c|c|}
\hline sample & $\begin{array}{c}\text { Sm } \\
(\mathbf{p p m})\end{array}$ & $\begin{array}{l}\text { Nd } \\
\text { (ppm) }\end{array}$ & $\begin{array}{l}{ }^{147} \mathrm{Sm} / \\
{ }^{144} \mathrm{Nd}\end{array}$ & $\begin{array}{l}{ }^{143} \mathrm{Nd} / \\
{ }^{144} \mathrm{Nd}\end{array}$ & $\begin{array}{c}\varepsilon N d^{1} \\
\text { at } 2.78 \mathrm{Ga}\end{array}$ & $\begin{array}{l}\mathrm{T}_{\mathrm{DM}}{ }^{2} \\
\text { (Ma) }\end{array}$ & $\begin{array}{c}\mathbf{R b}^{3} \\
(\mathbf{p p m})\end{array}$ & $\begin{array}{l}\mathrm{Sr}^{3} \\
(\mathrm{ppm})\end{array}$ & $\begin{array}{l}{ }^{87} \mathrm{Rb} / \\
{ }^{86} \mathrm{Sr}\end{array}$ & $\begin{array}{l}{ }^{87} \mathrm{Sr} / \\
{ }^{86} \mathrm{Sr}\end{array}$ & $\begin{array}{c}\mathrm{I}_{\mathrm{Sr}}{ }^{4} \\
\text { at } 2.78 \mathrm{Ga}\end{array}$ \\
\hline MUR 09-60 & 2.788 & 17.78 & 0.090541 & 0.510680 & -0.20 & 2978 & 241 & 313 & 2.2411 & 0.7830 & 0.6928 \\
\hline MUR 09-61 & 3.316 & 22.52 & 0.085884 & 0.510558 & -0.92 & 3014 & 221 & 263 & 2.4575 & 0.7919 & 0.6929 \\
\hline MUR 09-63 & 2.224 & 14.18 & 0.089507 & 0.510624 & -0.93 & 3021 & 127 & 272 & 1.3590 & 0.7566 & 0.7019 \\
\hline MUR 09-66 & 3.581 & 22.81 & 0.087162 & 0.510576 & -1.02 & 3022 & 119 & 484 & 0.7117 & 0.7302 & 0.7015 \\
\hline MUR 09-67 & 2.836 & 13.73 & 0.119418 & 0.511288 & 1.34 & 2913 & 225 & 111 & 6.0049 & 0.9237 & 0.6819 \\
\hline MUR 09-72 & 3.429 & 22.44 & 0.087834 & 0.510676 & 0.69 & 2920 & 229 & 312 & 2.1378 & 0.7772 & 0.6911 \\
\hline MUR 09-80 & 2.002 & 11.37 & 0.102811 & 0.509994 & -18.1 & 4227 & 103 & 218 & 1.3734 & 0.7820 & 0.7267 \\
\hline MUR 09-109 & 2.974 & 19.61 & 0.087780 & 0.510666 & 0.52 & 2930 & 193 & 282 & 1.9928 & 0.7768 & 0.6965 \\
\hline MUR 8a & 3.102 & 17.97 & 0.101329 & 0.510865 & -0.46 & 3014 & 132 & 160 & 2.4095 & 0.7928 & 0.6957 \\
\hline MUR $18 \mathrm{c}$ & 3.104 & 20.98 & 0.086311 & 0.510672 & 1.17 & 2889 & 216 & 268 & 2.3584 & 0.7940 & 0.6991 \\
\hline MUR 09-108 & 2.830 & 17.58 & 0.093023 & 0.510671 & -0.74 & 3050 & 230 & 246 & 2.7360 & 0.8067 & 0.6985 \\
\hline
\end{tabular}


Supplementary Table 2 - Poujol et al

\begin{tabular}{|c|c|}
\hline $\begin{array}{l}\text { Laboratory \& } \\
\text { Sample } \\
\text { Preparation }\end{array}$ & \\
\hline Laboratory name & Laboratoire Magmas \& Volcans, Clermont-Ferrand, France \\
\hline \begin{tabular}{|l|l|} 
Sample \\
type/mineral
\end{tabular} & Magmatic zircon \\
\hline $\begin{array}{l}\text { Sample } \\
\text { preparation }\end{array}$ & $\begin{array}{l}\text { Wilfley Table, heavy liquids, Frantz magnetic separator, handpicking under } \\
\text { binocular microscope; 1inch Epofix resin mount, lum polish to finish }\end{array}$ \\
\hline Imaging & $\begin{array}{l}\text { CL: RELION CL instrument, Olympus Microscope BX51WI, Leica Color Camera } \\
\text { DFC 420C }\end{array}$ \\
\hline \multicolumn{2}{|l|}{$\begin{array}{l}\text { Laser ablation } \\
\text { system }\end{array}$} \\
\hline $\begin{array}{l}\text { Make, Model \& } \\
\text { type }\end{array}$ & Resonetics/M-50E 193nm, Excimer \\
\hline $\begin{array}{l}\text { Ablation cell \& } \\
\text { volume }\end{array}$ & Laurin Cell ${ }^{\circledR}$ two volumes cell, Laurin Technic Ltd., volume ca. $1 \mathrm{~cm}^{3}$ \\
\hline Laser wavelength & $193 \mathrm{~nm}$ \\
\hline Pulse width & $<4 \mathrm{~ns}$ \\
\hline Fluence & $3{\mathrm{~J} . \mathrm{cm}^{-2}}^{-2}$ \\
\hline Repetition rate & $3 \mathrm{~Hz}$ \\
\hline Spot size & $26 \mu \mathrm{m}$ \\
\hline $\begin{array}{l}\text { Sampling mode / } \\
\text { pattern }\end{array}$ & Single spot \\
\hline Carrier gas & $\begin{array}{l}100 \% \mathrm{He}, \mathrm{Ar} \text { make-up gas and } \mathrm{N}_{2} \text { combined using the Squid } 囚 \text { device from } \\
\text { RESOlution Instruments. }\end{array}$ \\
\hline $\begin{array}{l}\text { Background } \\
\text { collection }\end{array}$ & 20 secs \\
\hline Ablation duration & 60 secs \\
\hline Wash-out delay & 30 secs \\
\hline $\begin{array}{l}\text { Cell carrier gas } \\
\text { flow }\end{array}$ & $0.70 \mathrm{l} / \mathrm{min} \mathrm{He}$ \\
\hline \multicolumn{2}{|l|}{\begin{tabular}{|l} 
ICP-MS \\
Instrument
\end{tabular}} \\
\hline $\begin{array}{l}\text { Make, Model \& } \\
\text { type }\end{array}$ & Agilent $7500 \mathrm{cs}$ \\
\hline $\begin{array}{l}\text { Sample } \\
\text { introduction }\end{array}$ & Via conventional tubing \\
\hline RF power & $1350 \mathrm{~W}$ \\
\hline Make-up gas flow & $0.98 \mathrm{l} / \mathrm{min} \mathrm{Ar}$ \\
\hline Detection system & Single collector secondary electron multiplier \\
\hline Masses measured & $204,206,207,208,232,238$ \\
\hline $\begin{array}{l}\text { Integration time } \\
\text { per peak }\end{array}$ & $10-30 \mathrm{~ms}$ \\
\hline \multicolumn{2}{|l|}{ Data Processing } \\
\hline Gas blank & 20 seconds on-peak \\
\hline \begin{tabular}{|l} 
Calibration \\
strategy
\end{tabular} & $\begin{array}{l}\text { GJ-1 used as primary reference material, } 91500 \text { used as secondary reference material } \\
\text { (Quality Control) }\end{array}$ \\
\hline $\begin{array}{l}\text { Reference } \\
\text { Material info }\end{array}$ & $\begin{array}{l}91500 \text { (Wiedenbeck et al., 1995) } \\
\text { GJ1 (Jackson et al., 2004) }\end{array}$ \\
\hline $\begin{array}{l}\text { Data processing } \\
\text { package used / } \\
\text { Correction for } \\
\text { LIEF }\end{array}$ & GLITTER $®$ (van Achterbergh et al., 2001) \\
\hline $\begin{array}{l}\text { Mass } \\
\text { discrimination }\end{array}$ & $\begin{array}{l}\begin{array}{l}\text { Standard-sample bracketing with }{ }^{207} \mathrm{~Pb} /{ }^{206} \mathrm{~Pb} \text { and }{ }^{206} \mathrm{~Pb} /{ }^{238} \mathrm{U} \text { normalized to reference } \\
\text { material GJ-1 }\end{array} \\
\end{array}$ \\
\hline $\begin{array}{l}\text { Common-Pb } \\
\text { correction, } \\
\text { composition and } \\
\text { uncertainty }\end{array}$ & No common- $\mathrm{Pb}$ correction. \\
\hline $\begin{array}{l}\text { Uncertainty level } \\
\& \text { propagation }\end{array}$ & $\begin{array}{l}\text { Ages are quoted at 2sigma absolute, propagation is by quadratic addition according } \\
\text { to Horstwood et al. (2003). Reproducibility and age uncertainty of reference } \\
\text { material are propagated. }\end{array}$ \\
\hline \begin{tabular}{|l} 
Quality control / \\
Validation
\end{tabular} & 91500: $\quad$ Concordia age $=1066.7 \pm 2.1 \mathrm{Ma}(\mathrm{MSWD}=0.45, n=10)$ \\
\hline
\end{tabular}

Isotopic Ratios for the 91500 Zircon Standards analyzed during this study:

Analysis_\# Pb207/U235 1 sig Error Pb206/U238 1 sig Error Rho

$\begin{array}{lrrrrr}91500 \# 1 & 1.854 & 0.025 & 0.1799 & 0.0022 & 0.9 \\ 91500 \# 2 & & & & & \\ & 1.865 & 0.025 & 0.179 & 0.0022 & 0.91 \\ 91500 \# 3 & & & & & \\ & 1.847 & 0.029 & 0.1803 & 0.0022 & 0.79 \\ 91500 \# 4 & & & & & \\ & 1.863 & 0.025 & 0.1796 & 0.0022 & 0.91 \\ 91500 \# 5 & 1.853 & 0.025 & 0.18 & 0.0022 & 0.87 \\ 91500 \# 6 & 1.85 & 0.024 & 0.1802 & 0.0022 & 0.91 \\ 91500 \# 7 & 1.851 & 0.025 & 0.1803 & 0.0021 & 0.86 \\ 91500 \# 8 & 1.859 & 0.024 & 0.1797 & 0.0021 & 0.9 \\ 91500 \# 9 & 1.856 & 0.024 & 0.1802 & 0.0021 & 0.88 \\ 91500 \# 10 & 1.845 & 0.024 & 0.1802 & 0.0021 & 0.89\end{array}$


Supplementary Table 1- Poujol et al.

\begin{tabular}{rccl} 
Sample & latitude (S) & longitude (E) & \\
\hline MUR 09-60 & $23^{\circ} 54^{\prime} 46.7^{\prime \prime}$ & $30^{\circ} 44^{\prime} 45.3^{\prime \prime}$ & \\
MUR 09-61 & ${ }^{\circ}$ & & \\
MUR 09-63 & $23^{\circ} 55^{\prime} 26.5^{\prime \prime}$ & $30^{\circ} 47^{\prime} 18.7^{\prime \prime}$ & \\
MUR 09-66 & $23^{\circ} 55^{\prime} 18.2^{\prime \prime}$ & $30^{\circ} 49^{\prime} 58^{\prime \prime}$ & western lobe \\
MUR 09-109 & $23^{\circ} 57^{\prime} 40.9^{\prime \prime}$ & $30^{\circ} 41^{\prime} 55^{\prime \prime}$ & \\
MUR 18c & $23^{\circ} 56^{\prime} 45.9^{\prime \prime}$ & $30^{\circ} 41^{\prime} 30.5^{\prime \prime}$ & \\
MUR 09-80 & $23^{\circ} 56^{\prime} 36.4^{\prime \prime}$ & $30^{\circ} 41^{\prime} 58.6^{\prime \prime}$ & \\
\hline MUR 09-67 & $23^{\circ} 50^{\prime} 15.7^{\prime \prime}$ & $30^{\circ} 58^{\prime} 58.8^{\prime \prime}$ & \\
MUR 09-72 & $23^{\circ} 48^{\prime} 55^{\prime \prime}$ & $30^{\circ} 57^{\prime} 19.6^{\prime \prime}$ & eastern lobe \\
MUR 8a & $23^{\circ} 49^{\prime} 02.9^{\prime \prime}$ & $30^{\circ} 58^{\prime} 59.2^{\prime \prime}$ & \\
\hline MUR 09-108 & $23^{\circ} 58^{\prime} 20^{\prime \prime}$ & $30^{\circ} 40^{\prime} 33,6^{\prime \prime}$ & Willie pluton \\
& & & \\
\hline
\end{tabular}

